\title{
Reviews and Short Notices
}

\section{General}

Gardens and Green Spaces in the West Midlands since 1700. Edited by Malcolm Dick and Elaine Mitchell. University of Hertfordshire Press. 2018. xvi +212 pp. £16.99.

Writing about the history of gardeners and gardens is a tricky business. No longer is the focus on men like 'Capability' Brown and the great landscape gardens of the eighteenth century, but rather on less well-known gardeners and designers, the gardens of working people and public parks. Discussing William Shenstone's gardens at The Leasowes in Halesowen with its obelisk and water features, John Hemingway is able to draw on 'archaeological findings and ... copious writings and watercolours', but several of the contributors to this engaging survey of gardens and green spaces in the West Midlands confess that there are gaps in the records they are using. An interesting figure - such as Lydia Yates who ran a nursery in Derby in the 1780s - might appear and then vanish from sight or something unexplained might happen - such as the sudden closure of Vauxhall gardens in Birmingham in 1850 - or a source that might have been expected to survive - such as the garden plans for Joseph Chamberlain's Highbury - has not.

Malcolm Dick and Elaine Mitchell set out a bold ambition in their introduction. They intend to rescue their gardeners from 'the enormous condescension of posterity'. (Edward Thompson, himself a heroic gardener at his country house in Worcestershire, would have smiled at this co-option of his famous phrase). Dick himself does not contribute a chapter to this collection, but Mitchell seeks to tell the story of Vauxhall pleasure gardens in Birmingham, which opened at some point between 1738 and 1745. Anyone with an interest in Birmingham in the eighteenth and nineteenth centuries will be aware of these gardens, but will know little about them. Drawing on a watercolour from 1850 and newspaper advertisements, Mitchell now provides us with their story, as far as it can be told. Biographical information on the founders of the gardens, or the artist who produced the watercolour, is unavailable, but we learn about who visited the gardens (there was an admission charge of one shilling) and what they did there (listened to music and watched fireworks and cock fights). Mitchell concludes by offering a persuasive explanation for the demise of these gardens.

This difficulty in securing evidence is clear elsewhere in the volume. Harriet Devlin recovers the stories of the private gardens and woodland walks created at Coalbrookdale, but falls back on a good deal of contextualization. Having 
said that, it is a very nice little essay, most enjoyable to read. Dianne Barre draws attention to the nurserywomen of Derbyshire and Birmingham and is often able to find only fragmentary information about them. Yet again, what she does tell us about women such Frances Sprinks, who created a grotto in the garden behind the manufactory she inherited from her husband, or Anne Sandys, who ran a profitable nursery, is fascinating. In drawing attention to something that badly needs drawing attention to, this is the most important essay in the collection.

With their essays on the work of 'Capability' Brown - as well as his critics Uvedale Price and R. P. Knight - in Herefordshire and on the restoration of the landscape around Hagley Hall in Worcestershire, David Whitehead and Joe Hawkins ensure - quite properly - that attention continues to be paid to these beautiful creations of the eighteenth century. Maureen Perrie and Katy LaytonJones both offer a useful contrast to these landscapes. Perrie focuses on the houses the ruling elite of Birmingham built for themselves in the late nineteenth century - Joseph Chamberlain's Highbury and Richard Cadbury's even more impressive Uffculme. Layton-Jones offers an original contribution by demonstrating the coming together of industrialization and gardens in public parks, with their iron bandstands and red-brick bridges. Finally, Clare Hickman takes Bromsgrove as a classic example to demonstrate how exposure to the open air formed part of the treatment offered for ill health in the late nineteenth and early twentieth centuries.

This collection is made up of papers offered for a conference at the University of Birmingham in 2014. Inevitably this means that the editors have to work with what is offered them rather than plan what ought to have been included. There is no discussion of the very important botanical gardens that opened in Birmingham in 1832 and about which there are certainly new things to say - and the walled gardens at Castle Bromwich Hall and the Arts and Crafts villa garden at Winterbourne are other notable absentees. Nonetheless, what we get here is a very appealing book - a carefully researched and very readable collection of essays which open up new themes. It should be added that, as with a previous publication from the Dick/Mitchell stable, it is beautifully illustrated, with numerous colour plates.

Australian National University

STEPHEN ROBERTS

\section{Studies on Montesquieu: Mapping Political Diversity. By Rolando Minuti.} Springer. 2018. xiii +202 pp. $£ 79.00$.

This book is the culmination of years of research, reflection and writing on the wide range of travel literature consulted by Montesquieu. While much of this reading went hand in hand with developing commentary and critical insight applied to editing key volumes of Montesquieu's Euvres complètes, Rolando Minuti is able in this volume to place his observations and analyses in a more developed and systematic way than is made available in an editorial enterprise of that nature. And while some of these chapters have been published previously elsewhere and in other forms, the author's editorial work on the Euvres complètes also helped to deepen insights, thereby giving him the opportunity to fine-tune previous arguments and positions. This collection thus provides an updated 
and relatively systematic account of how the author suggests we come to terms with Montesquieu's vast commentary on the non-European world and on nonChristian faiths and peoples.

The project is not an easy one. Not only does it cover a vast amount of terrain and diversity of topics, but when covering the background and sources of Montesquieu's own claims about the non-European world it requires knowledge of a wide range of texts. In addition, given clear anxieties about facets of Montesquieu's analysis that appear effectively to champion the West and to undervalue too easily the experience of other peoples based on factors of history, climate or religion, despite Montesquieu's overt defence of toleration in principle, it can be a difficult terrain to analyse.

Minuti nonetheless does so in a frank and systematic way, devoting each chapter to either one region of the world, or one issue of religious difference. He looks to identify the key sources Montesquieu drew from in developing his reflections, as well as how he used those sources and how his observations regarding that topic evolved from Lettres persanes (1721) through to his later Esprit des lois (1748) and after. Discussion of the literary sources from which Montesquieu drew his knowledge of the non-European world is particularly useful, as it offers insight for the reader into how Montesquieu worked from these sources and how well read he was on each of the themes addressed.

The first chapter is devoted to discussing the relative status of physical and moral causes in Montesquieu's work. Minuti defends the primacy of moral causes in his reading of Montesquieu, all the while acknowledging that this appears not to spare Montesquieu from regarding the European context as especially well suited to the practice of liberty. This is brought to light in various ways in subsequent chapters where Minuti reflects on various depictions of despotism in Montesquieu's work. His analysis highlights the degree to which Montesquieu sought to come to terms with the diversity of history and cultural development in different parts of the world while also seeking to place his knowledge within a broader framework from which he could derive deeper meaning.

In the case of Japan we are presented with a state that is considered exceptional due to the harshness of its laws linked it would appear to the relative weakness of religion, at least as exercising any civil function. Russia also is depicted as a despotism, but in a different way from Japan. Minuti demonstrates the complicated analysis Montesquieu brings to bear upon the Russian case, acknowledging that there were certain features of social structure and climate that militated against despotism, but also features of history that appeared to favour it, given the long period of rule by the Tartars, and a modernizing ruler in the person of Tsar Peter who sought to change society too much and too quickly by legal fiat. Minuti's discussion of Montesquieu's analysis of the differing ways in which ancient peoples and especially the Romans established their empires and extended their influence in contrast to later peoples such as the Tartars sheds new light on the complexities of political influence, subjugation and its legacies. Mughul India, as discussed in chapter 5, offers yet another model of despotic rule that left a lasting and possibly irreparable legacy in India. What emerges from these various accounts is not only a broader appreciation of the complexity and attention to detail found in Montesquieu's work, but also more generally a realization that in the midst of a language of caricature, his depiction of actual 
instances of despotic states was much more textured and variegated than is often acknowledged.

In addition to shedding light on instances of despotism in Montesquieu's work, Minuti's discussion of the various bodies of travel literature also invokes an interesting analysis of divergent models of colonial economies, contrasting that of the Spanish in Mexico (of which Montesquieu was vociferously critical) and those of other states in the Americas. This discussion offers the basis for a more refined consideration of Montesquieu's defence of commerce. In addition, towards the latter part of the book, Minuti addresses the issue of religion and tolerance, both within Europe and vis-à-vis other faiths such as Islam. Again, while we can acknowledge the importance of Montesquieu's denunciation of the Inquisition and of his call for what he called 'external toleration' in his own context, it is also clear that his treatment of Islam was less generous than it could have been. Still, Minuti also convincingly suggests that what Montesquieu considered most valuable about his analysis was not his enumeration of the positives and negatives of doctrine, but the deeper analytical move to consider religion not as a set of isolated dogmas, but as a set of principles embedded in a broader social and political context. This is where the book ends. While as a reader I might have wished for a more general concluding chapter that discussed the broader uptake or lessons of these chapters for a contemporary appreciation of Montesquieu's work, it may have been the author's intention to let each reader sort that out for themselves. The reader is left in appreciation of the relative intricacy of Montesquieu's analyses and the depth of his understanding, but also with misgivings about some of his conclusions regarding peoples outside the West.

In general terms, then, this work is valuable on a number of fronts. It provides a thorough and thoughtful account of the various sources Montesquieu drew from in developing his analysis of a number of areas of the non-western world. It also sheds light on how Montesquieu came to use those sources vis-à-vis his contemporaries while depicting his own version of those societies in the context of his broader analytical schema. Finally, it also offers helpful ways of coming to terms with or framing Montesquieu's engagement with various facets of the nonwestern world that allow the reader to appreciate the depth and extensiveness of Montesquieu's research while not fully absolving him of errors in judgement.

University of Toronto

REBECCA KINGSTON

The Wild Within: Histories of a Landmark British Zoo. By Andrew Flack. University Virginia Press. 2017. xiii + 258pp. \$39.50.

The so-called 'rational amusement' historically offered by zoos is, as Andrew Flack reminds us in this excellent book, a rather difficult beast to master. Bristol zoo - the case study around which the book revolves - has been trying to balance, or appease the advocates of, science and spectacle for over 180 years now (the zoo opened to the public in 1836). Although the fact that it still exists points towards some kind of success, it has undoubtedly been a bumpy ride, in which the institution has not always been on the right side of public opinion. It seems that every zoo is always one depressed polar bear or over-eager chimpanzee away from a public-relations disaster. The fortunes of animals can move especially 
fast: in the 1960s, for instance, Bristol owned two very popular white tigers, who almost singlehandedly pushed up visitor numbers. By 1985 the same two animals had been 'cast out of the collection', not for any misdemeanour, but because their value - both financial and scientific - had diminished in the face of evidence that their whiteness was not a sign of gracious divinity, but an unfortunate genetic mutation. Zoos, like museums, present themselves to their public as logical institutions, with carefully managed collections and consistent clearly stated aims. However, as Flack reveals again and again, they not only develop in a haphazard manner but regularly defy easy explanation. Faced with some dark historical material - the frequency of animal deaths in the early days makes for particularly hard reading - it would have been easy for Flack to write a damning indictment of Bristol zoo, setting it up as yet another model of the city's increasingly unmanageable imperial legacy. The reality is that, while Flack doesn't shy away from the difficult stories or questions - humans don't come well out of this narrative, as you'd expect - this remains a nuanced, open-minded and sensitive account, supported by clear, incisive prose. He wants us to see the zoo as a 'hybrid' and 'global' space; to understand its animals as 'entities of multifaceted encounter'. Heavily informed by the growing field of Animal Studies, and ordered according to recurring themes (including value, visual logic, power balances and anthropomorphism), the book is likely to frustrate readers looking for a standard year-by-year history of Bristol zoo. Despite its relative shortness, this is more of a sprawling history, moving with ease from the personal to the political, from Charles Darwin and Donna Haraway to Where the Wild Things Are and Creature Comforts. It is, in a sense, a series of six interconnected essays about human-animal relationships, all of which happen to focus on Bristol zoo. On this basis it deserves - and should garner - a much wider audience, not just those interested in the histories of zoological gardens at large (which should be anyone who has ever visited a zoo), but anyone interested in questions surrounding human notions of 'wildness' (which should be anyone who has ever lived).

University of Leicester

SAMUEL SHAW

\section{Bloomsbury Scientists: Science and Art in the Wake of Darwin. By Michael Boulter. UCL Press. 2017. xxii + 175pp. £15.00.}

Ever since Darwin's theory of evolution made its way into the public sphere, scholars from various backgrounds have tried to understand how his theory was influenced by, and impacted on, Victorian political and social culture. Curiously enough, the historiography dealing with the evolutionary theory has become so overcrowded that after the turn of the second millennium, historians acknowledged that the phenomenon was morphing from an 'industry' into a whole 'enterprise'. Michael Boulter's book does not follow categorizations as his research stands as a eulogy which focuses on the urban nexus between scientists, intellectuals and artists from the London district of Bloomsbury. Written in plain language, the story departs from the author's own experience in the industrial city of Leicester in the 1950s where growing up in a poor working-class environment was a decisive factor in his decision to study biology at UCL. 
The story begins with the comparison of two funerals: those of Charles Darwin in 1882 and Karl Marx in 1883. The attendees were clearly distinct from each other: at the first funeral, the rich and privileged who had trained at Oxbridge, and at the second, social reformers who stood against all forms of exploitation. Although their political beliefs were in opposite corners, the common ground between these two groups was their strong faith that 'science would solve the world's problems' (p. 3). In other words, as every leap of faith has its own apostles who thrive for the betterment of society, Victorian science and art were also represented by strong figures, such as the eugenicist Francis Galton, the biologist T. H. Huxley, the painter Roger Fry or the author H. G. Wells. Throughout the successive chapters of Boulter's book, the narrative centres on the zoologist Ray Lankester and the question of how various approaches to the theory of evolution by natural selection gave so many eclectic answers while leading towards racist and class-based theories such as eugenics. If quantification was important for scientific objectivity, the lack of evidence concerning the laws of inheritance made way for the appearance of eugenics, which was used by state policies in order to select the poor and 'feebleminded' from those population groups who 'inherited' both their wealth and intellectual capacities. Inspired by Francis Galton's measurements in anthropometry, the science of eugenics was later strengthened by Karl Pearson's statistics, which brought together supporters not only from elite circles but also socialists and middle-class women eager to 'advance their suffragette cause' (p. 103). It was a common practice for the British intellectual establishment to join in clubs and secret societies. A good example cited by Boulter is the 'Cambridge Apostles', at whose meetings matters of philosophy, biology and mathematics were discussed by the likes of Bertrand Russell, Alfred Whitehead and John Maynard Keynes. This kind of practice made possible new opportunities for the young students which created new power relations inside academia. In this vein, Boulter identifies the Post-Impressionist painter Roger Fry, who joined the Cambridge society and ended up as 'one of the first professional artists to have trained as a scientist' (p. 70). On the other hand, 'outsiders' with an impecunious background like H. G. Wells passed through various struggles during their studies - though in Wells's case, he became a leading 'exponent of science fiction' due to his 'visionary' novels that illustrated the connection between science, arts and the future of social evolution (p. 69).

Within this context, Edwardian Bloomsbury brought to the surface more ties between science and arts and reoriented life from the laboratory to the openings of nature, a shift that culminated in what we know today as the science of ecology. At that time, ecology focused more on its application in agriculture and talked less about climate change and natural disasters. However, it soon became a precious instrument for the economic growth of British imperialism. For instance, Marie Stopes, who became one of the first women to teach in British academia, apart from her research on birth control and palaeobotany, aimed by her studies of coal mining to 'find the most productive form of energy readily available at the time of the First World War' (p. 80). On the other hand, William Bateson's rediscovery of Mendel's law of inheritance, in a taxi riding along Bloomsbury's streets, encouraged the appearance of 'a new breed of biologists'. At that time, biologists were divided between those from London who were advancing the idea that the 'mechanism of evolutionary change was competition by natural selection', and those based in Cambridge who insisted that "new species originated by sudden 
mutation at the genetic level' while evolution happens inside cells (pp. 93-4). The dispute settled down after the First World War with the help of the modern synthesis, when discussions shifted towards molecular specialism and population genetics. As Boulter notes, 'supporters of Mendel were right in assuming that Darwinism needed a particulate mechanism for inheritance, that mutation took place within the cell and that selection happened outside each organism, in populations and their environment' (p. 150). From that point onwards, the history of genetics culminated with Watson and Crick's discovery in 1953 of the double helix structure of the DNA molecule that showed how every cell in the organism works.

In terms of the artistic manifestations of the interwar period, Boulter briefly mentions the Rebel Art Centre and the Vorticist movement together with their journal Blast; but more space could have been given to the artistic relationship with science of the critics of Bloomsbury Post-Impressionists. A point in case is the Design and Industries Association (DIA), whose members were trying to illustrate the elitist tenets of the fine arts, with the aim of bringing artistic expression closer to popular culture. In his work on London modernist art, Saler Michel identified the DIA group as the 'genuine English avant-garde'. Their general faith was that 'both physics and biology appeared to be revealing a world where the conjunction of matter and spirit could be understood by science and revealed by art'. In a similar vein, other figures worth mentioning are the anarchist and art critic Herbert Read and the Hungarian socialist painter László Moholy-Nagy, whose writings frequently addressed the role of biology in shaping society. Last but not least, Christina Lodder, in her biographical sketch of the Russian sculptor and architect Naum Gabo (who also had a scientific background), argued that after his exile from the Nazi regime he moved to London and lived in Bloomsbury. A representative figure of Bauhaus constructivism, Gabo insisted in 1938 at the London Gallery that 'the creative force of art is the only one from which the whole progress of all our spiritual disciplines including science drives and grows'.

All in all, Bloomsbury Scientists gives the general reader a quick snapshot of the landscape that was painted with scientific brushes and evolutionary paint. The story is told with great passion and consideration for the names that contributed to this entangled history of science and arts in Bloomsbury London.

Oxford Brookes University

COSMIN KOSZOR-CODREA

\section{Theoretical Perspectives on Historians' Autobiographies: From Documentation to Intervention. By Jaume Aurell. Routledge. 2016. xii + 279pp. £115.00.}

Jaume Aurell's Theoretical Perspectives on Historians' Autobiographies is a book every historian and theorist of history wishing to engage in professional self-reflection would do well to read - as, indeed, would anyone interested in lifewriting as a genre. Much like its predecessor, and still most obvious rival, Jeremy Popkin's brilliant History, Historians, and Autobiography (2005), Aurell's work is theoretically sensitive in its attempt to locate historians' autobiographies on the continuum of historical and fictional writing. In addition to an exploration of the particular, potentially more factually exacting reading pact governing such 
autobiographies, however, Aurell's approach goes beyond Popkin's in focusing on the connection of the stylistic and literary strategies adopted by authors with their history-theoretical assumptions - with, that is to say, these historians' beliefs about what history is and what it is they do professionally in constructing their discrete stories. By reading autobiographical texts concurrently with explicitly historical ones, Aurell also presses home the point that autobiography can usefully be seen as a parallel historiographical practice in its own right.

All this more than justifies revisiting what may on first impression appear to be a closely circumscribed topic. In fact, already in the introduction, Aurell quickly banishes any impression of the topic's exhaustion with a surprising figure: his study is based on a reading of around 450 historians' autobiographies (p. 19); arguably a genre in its own right. These texts (essays as well as monographs) span a period of 100 years, and Aurell ends up discussing them in six fairly distinct categories of historical autobiography - categories which serve excellently to highlight both the diversity in historians' attitudes to scripting their selves as well as the 'historicity' of their self-understanding and stylistic sensibilities.

Based on such extensive reading, the journey the book takes the reader on is no less impressive. Beyond offering disparate life stories, these texts, when brought together in this way, suggest 'the story of a generation, an era, a discipline, a change in intellectual perspectives over time' (p. 11). And this is indeed the repeating motif in most of Aurell's formulations: he wants to tell the broader story of the 'academic text', situating these autobiographies in that story as - as he provocatively puts it - 'artifacts of historiographical evolution' (p. 5) and admirably demonstrating their usefulness for intellectual history. This thesis of a pronounced change (or indeed 'evolution') in historians' overall writing sensibilities occasions, quite naturally, the framework he presents for conceiving of the transformation of 'historical' writing both in its strict disciplinary sense and as reflected in the autobiographies examined.

Accordingly, while the six 'autobiographical-historiographical' categories that Aurell proposes clearly have a heuristic function - or, as he more poetically and concretely puts it, they are 'unstable' (p. 19) and never 'pure' (p. 265) - they also introduce a rather compelling historical emplotment. Aurell's first two categories, 'humanistic' and 'biographical', are designed to fit autobiographies by historians of the interwar generation, commonly focused on their academic and intellectual constitution; the categories of 'ego-historical' and 'monographic' are in turn matched with autobiographies from the post-war generation, expressing a desire for rigorous scholarship at times combined with explicit political engagement; and the last two, the 'poetic' (or 'postmodern') and 'interventional', are temporally identified with autobiographies written after the 1970s, with their foregrounding of irony and personal interests (pp. 22-4). Nevertheless, to reiterate his caveat concerning instability, these categories should not be read too literally. Obviously there are overlaps, continuities as well as contradictions to be found in such a taxonomy and Aurell rightly emphasizes, for example, the similarities between his monographic and interventional authors, the most literally ideological of these groupings.

A criticism that could be made of Aurell's investigation is the limited range of countries and language-groups he tackles. Although he points to some geographical variation, this mainly involves a division marked by the Atlantic. Yet, and despite the decision to focus on 'classic' texts (a quality that has, 
interestingly, been the object of some of his more recent theoretical work), one of the principal conclusions of this journey is that historians are context-bound and any ideals of what history is need, equally, to be understood in that context. Furthermore, this is reflected in their autobiographical writing: 'Historians use different methodological and formal strategies to engage the story of the self, depending on the theoretical conceptions of history they deploy as historians' (p. 14). At the same time, reconstructing historiographical attitudes from the literary styles utilized by historians in their autobiographies is, perhaps, another proposition not to be taken too literally.

In making these claims, Aurell in no way underplays the significance of historians as, in one way or another, 'public intellectuals' (p. 9), regardless of their particular autobiographical sensibilities. Yet, in line with the broader discussion on 'academic autobiography', and closely following the lead of Popkin, he proposes that a shift can be discerned in their role as such. In Aurell's story, this is marked by a move 'from documentation to intervention', as stated in the book's title. According to Aurell's reading, the search for new forms of representing corresponds with changing attitudes to objectivity in the human sciences, with the historians he considers 'postmodern' and 'interventional' most obviously breaking with tradition and attending keenly to the personal too. $\mathrm{He}$ even reads some 'frustration' (p. 263) with conventional history writing into this: 'Simply, historians' autobiographies are among the more valuable expressions of the postmodern rejection of history's traditional cult of objectivity' (p. 16).

To me, Aurell's attention to 'experimental' historians like Carolyn Steedman, Robert Rosenstone, Gabrielle Spiegel, Natalie Zemon Davies and Geoff Eley is one of the principal offerings of this book. And it is precisely with respect to their postmodern and interventional texts that the theoretical questions he asks really come into their own. For these authors, autobiography clearly offers the kind of working 'laboratory' for formal experimentation and for testing the limits of disciplinary epistemic assumptions that he postulates. Yet, while this is where the challenge posed to conventional historiographical practice by historians seeking to historicize themselves stands out in sharpest relief, Aurell reminds us of the connection between 'personal itineraries' and professional obsessions in the work of historians of all stripes - as well as the tensions and conflicts this can create. In addition to being particularly well balanced and thought-provoking, this book helps to dispel the all too often repeated criticism that historians today continue to lack self-understanding and theoretical awareness.

Tallinn University

KALLE PIHLAINEN

\section{Medieval}

Journal of Medieval Military History $X V$. Edited by Leif Inge Ree Peteresen and Manual Rojas Gabriel. Boydell. 2017. x + 228pp. £60.00.

One of the great strengths of the Journal of Medieval Military History $(J M M H)$ is its broad-ranging and eclectic content, always (and sensibly) arranged chronologically. Previously, it has published only one themed volume - number IX from 2011, focusing (very successfully) on soldiers, weapons and armies in 
the fifteenth century. With volume XV, it once more reverts to a theme, this time being 'Strategies'. It is a topic which has encouraged lively debate in the pages of $J M M H$ before; it is entirely fitting that it should receive its own dedicated volume. Nine essays address this central issue of medieval warfare, from the late third century (which can barely be called medieval) to the late thirteenth century (with some limited toe-dipping beyond this) and spanning a wide geographical reach that includes a trio of Iberian essays, reflecting the origins of the majority of these pieces from a conference at Cáceres in 2009. The range, therefore, is rather odd, starting in the pre-medieval era but eschewing the late medieval period. Nonetheless, and despite lacking the cohesiveness of volume IX, the result is still extremely fruitful and stimulating.

Bernard Bachrach kicks off proceedings with a lengthy and suitably combative essay that looks at late Roman defensive strategy through the lens of fortification of the urbes of Gaul in the late third century, part of the Romans' 'vast program of military construction through large parts of the empire' (p. 3), undertaken at great expense. Bachrach asks if this was part of a grand strategy and concludes it was 'a long-term imperial strategy' (p. 31) with elements amounting to a grand strategy. Defences were built as 'a continuous expansion, as needed, intended to deal with a situation in which barbarian blue and brown water operations in Roman territory were becoming more effective' (p. 25). The crisis faced by the Roman empire at the time was not, he argues, so critical west of the Rhine. Here the concerns were not those of commanders in the eastern empire facing major barbarian incursions, which Bachrach dismisses for Gaul (even the infamous one of 275-6), but of the serious threat raised by raiders from the coast, especially the 'Saxon shore', which required a defence-in-depth response.

Leif Peteresen takes us through the next few centuries up to 800 to explore early Byzantium's response to northern barbarians by means of its client management on its northern frontiers. Byzantium faced a host of new and existing challenges, not least, as Petersen shows, when facing such threats as those posed by the Slavs and manpower shortages from plague in the sixth century, the Umayyad caliphate until 740, and the Bulgars from the late seventh century. Petersen argues that, overall, Byzantium's strategy of client management proved very successful.

Richard Abels travels further north to examine English strategy against the Vikings, and how Æthelred II failed to emulate Alfred the Great's much more joined-up and mutually reinforcing approach. The English faced much the same dilemma as Roman Gaul did in Bachrach's essay - that of sea-based raids and invasions - which shaped the history of middle and late Saxon England. Here Abels convincingly questions Keynes's influential argument from thirty years ago that the threats faced by Æthelred and Alfred were not comparable; in so doing, Abels reiterates his case for Alfred's pragmatic ability 'to plan strategically on a grand scale' (p. 69) while \#thelred and his advisers 'lacked Alfred's strategic vision' (p. 84); it was this 'that cost him his kingdom' (p. 70). Even Æthelred's plans of massive naval preparations came to naught, as the Anglo-Saxon Chronicle laments. As Levi Roach has recently shown in his biography of $Æ t h e l r e d$ (too recent to be addressed in this essay), the king was more sacerdos than miles. Alfred was both.

Matthew Bennett then goes global, with an assessment of the Normans' highly effective and consistent approach to a 'world domination' strategy, combining diplomacy, ideological vision, family connections and, of course, mastery of 
war and military technology (the latter not least in fleets and fortifications - a 'wood and stone' strategy), thereby establishing a 'template for a strategic model employed by the Franks in general' (p. 101). In this he makes a deferential nod towards Robert Bartlett.

Luis Garcia-Guijarro Ramos begins the Iberian trilogy with his study of the geopolitical strategy of the papacy towards the Catalan counties, $c .1060-1100$, persuasively arguing that this was mutually beneficial, but more so in real terms for comital power. One important factor here was monastic exemption, 'which tied abbeys directly to the papacy while restricting the intervention in their affairs of bishops whose sees were occasionally located in foreign lands and who might thus be inclined to foster alien secular interests' (pp. 104-5). The arrangement was significantly altered, argues Ramos, by the Gregorian reforms and the Dictatus Papae (dated 1075). Understandably, the Reconquista and First Crusade loom large.

Alfonso VII of Léon-Castile comes under the spotlight in Manuel Rojas Gabriel's insightful and absorbing analysis of the sustained strategic logic in alAndalus between 1145 and 1157. Rojas convincingly shows that Alfonso's taking of Almeria in 1147 owed less to crusading zeal and more to pragmatic regional concerns, where united fronts of the fragmented and competing Iberian Christian powers against the Muslims 'were more the exception than the norm' (p. 133). Maria Garcia Oliva extends the period until 1230, rightly demonstrating the precedence of pragmatic expediency over religious ideology in her careful analysis of alliances between León and the Almohads, the kings of León wisely using political and diplomatic relations in support of their expansionist strategy against the Andalusi territory, 'first to preserve their expansion zone through alliance with the Muslims, and then, when Alfonso IX went on the offensive, to gain the military cooperation of forces from other kingdoms in his campaigns' (p. 183). In her lengthy and detailed piece, she explains why Leonese territorial advances were delayed until the early thirteenth century and how this influenced their strategy for annexing Muslim lands.

We then move back north yet again for John Gillingham's contribution on Henry of Livonia and the conquest of Estonia in the early thirteenth century in which total warfare - centred on raiding and slave-taking - was employed as a tried and tested strategy. Henry is an invaluable chronicler of warfare and had more experience of it than he would have wanted. Through Henry, Gillingham portrays the grim reality of conflict in Estonia, where pagans 'disinterred the bodies of their dead, who had been buried in cemeteries, and cremated them according to their native pagan custom' (pp. 189-90). The advanced military technology of the Christian invaders was, as Bennett discusses in his essay, both greatly superior and instrumental in their success. But Gillingham also shows the central importance of low-tech factors - fear and 'destructively predatory warfare' (p. 197) - in which 'the killing of leaders was an important war aim' (p. 203). Henry's chronicle is not short of examples.

Finally, John France's relatively short but revealing essay on the English longbow shows how tactics could be influenced by strategy. In so doing he states that 'archers were not invariably present in battle, and often they were not very effective' (p. 217), but adding that for the later Middle Ages they were famously central to English campaigning. A measured overview of the longbow and its illustration in contemporary texts is followed by an explanation of how and why 
the contractual indenture system was so important, whereby local knowledge and recruitment 'established a relationship between the armoured men, whose closeorder formations were so essential to the new tactics' (p. 225).

This is a consistently excellent volume in an established and justifiably respected series.

University of Plymouth at Strode College

SEAN MCGLYNN

\section{The Medieval Military Engineer: From the Roman Empire to the Sixteenth Century. By Peter Purton. Boydell. 2018. xiv + 351pp. £60.00.}

Peter Purton has made an important contribution to our understanding of the development of medieval technology. In his impressive new work, The Medieval Military Engineer, he explores the continuity and evolution of military skills throughout the Middle Ages. This period covers the late Roman empire all the way through to the end of the fifteenth century. His primary focus is on the states of Latin Christendom but also incorporates the Byzantine empire, the Islamic powers of the Near East, and China. The concept of engineer, derived from the Latin ingeniator, or creator of machines, is used here in a broad sense to incorporate all professionals whose technological skills were employed in warfare including carpenters, masons, shipwrights, gunners, and others. As noted by Purton, few studies have focused on these workers, in part due to difficulties with finding suitable evidence. Yet his expertise in the field of medieval military history means that he is well suited for accomplishing this task. His previous publications include an excellent two-volume history of the medieval siege that covers the same period and geographical area. This is reflected in the bibliography of the present work, which details an extensive list of printed primary and secondary sources.

Chapter 1 begins by outlining the purpose of the book and Purton's main research questions. These include establishing who engineers were, how their status changed over time and where they acquired their skills from. He also poses the problem of establishing how technological change came about and how ideas and knowledge travelled across societies. This is followed by a discussion of the evidence used to address these questions. It is to his credit that he draws upon a wide range of sources, including historical documents, such as chronicles, government records and technical treatises, as well as the results of archaeological research and architecture. The remaining six chapters have a chronological format with sub-chapters focusing on specific areas such as 'science and technology', 'mining' or geographical regions. This means that the discussion ranges widely from exploring the use of siege weapons during military operations, building techniques, technical treatises and other aspects of the topic. Yet Purton does a good job in drawing together the different strands to maintain a coherent narrative. The book concludes with a postscript that briefly discusses technological developments that took place in the sixteenth century. An appendix is also provided which lists the names of recorded military engineers and miners in the service of the kings of England from 1130 to 1230 using the published Pipe Rolls of the Exchequer. Definitions of technical terms are listed in the glossary and the text is amply illustrated with black-and-white photographs and other images. 
A key theme of the book is identifying when and why technological changes took place. Often this took the form of enhancements to earlier types of weapons or equipment that had ancient origins. Improvements in stone-throwing weapons culminated in the trebuchet in the thirteenth century, whereas the fifteenth century saw the innovation of carvel shipbuilding, which made it possible for Europeans to venture on long-distance voyages of discovery around the world. Yet the most significant development, namely the introduction of gunpowder weapons, was entirely new. Over time this not merely transformed the course of warfare but also helped to usher in changes that marked the end of the medieval world. Purton cites economic and social developments as being a key driver of technological innovations. An expansion in the size of cities and governments led to an increase in demand for skilled workers, whose status consequently grew over time. This was particularly significant as artisans were as likely to be employed on civilian as well as military projects. Purton also attempts to determine the relationship between written knowledge and practical skills through an examination of military manuals. Many of these works, particularly in earlier centuries, looked back to earlier classical writers such as Vegetius, a situation that only started to change in the fifteenth century in response to gunpowder weapons. Establishing whether these texts had a direct influence on how artisans acquired their skills is a difficult task to accomplish with any precision. He makes a valiant effort to do this, but the nature of the surviving evidence means that it is often impossible to prove direct links.

One of Purton's central arguments is that knowledge of military engineering skills was retained after the fall of the western Roman empire in the fifth century. He makes a compelling case for the retention of knowledge in the Byzantine empire and the Islamic states of the Near East but is less convincing when it comes to Latin Christendom. What little evidence does survive instead suggests that many skills, including knowledge of creating siege weapons and bridges, were lost and only reacquired later. Purton's reliance on using the best available sources for every period also means that the focus of the book is slightly unbalanced. The technological skills of the Byzantine empire and Islamic states are discussed in detail in the early chapters, but after the thirteenth century the latter are only infrequently mentioned and the former scarcely at all. Yet these are only very minor criticisms of an otherwise excellent and ambitious book which fills a gap in the literature. It should be essential reading for all scholars interested in the military and technological history of the Middle Ages.

University of Southampton

DAN SPENCER

\section{The Peterborough Version of the Anglo-Saxon Chronicle: Rewriting Post-Conquest History. By Malasree Home. Boydell. 2015. x + 184pp. £60.00.}

The Peterborough or ' $E$ ' version of the Anglo-Saxon Chronicle is the set of annals that continued to be written for the longest time after 1066, firstly at Canterbury and subsequently from $c .1121$ at Peterborough. Malasree Home's close reading and analysis of its text is an important contribution to our knowledge of how the twelfth-century monks of Peterborough both viewed and were shaped by an institutional past that went back to the abbey's 
seventh-century foundation and its restoration in 963 and to the explosion of historical writing that took place in England during the twelfth century. After stressing, as is nowadays customary, that the versions of the Anglo-Saxon Chronicle should be treated as distinct texts, the author advances rapidly to the statement that it is "essential to draw attention to the cultural hybridity of the "E" text' (p. 5). Through references to the Latin histories of the time, most notably those of John of Worcester, William of Malmesbury and Henry of Huntingdon, she proceeds to an emphasis on the diversity of twelfth-century historical writing and to the argument that the Peterborough text should not be seen as an eccentric attempt to continue a vernacular tradition in the face of a new dominant Latin culture.

By locating the Chronicle's text within the context of other texts written at Peterborough that includes an early house history, the Relatio Heddae, the cartulary known as the Liber Niger, and the later house chronicle of Hugh Candidus, Home is able to make her case for cultural hybridity and the authors' variation of the annalistic form, with the role of interpolated charters and accumulated non-charter-based memory being central to this. She also demonstrates significant differences between the 'First Continuator' who wrote the annals covering the period from 1121 to 1131 and the 'Second Continuator' who contributed the coverage from 1131 to 1154 . These sections tell us a huge amount about the way in which the anonymous authors wanted to protect their abbey's interests and how they interacted with the wider world of the English kingdom and beyond. Among the many original contributions is a reinterpretation of how we should view the famous - or more likely infamous - passage in the 1137 annal that has been at the heart of so much writing on 'the Anarchy', with the author concluding that 'the real focus ... is not the narrative of disaster, but a narrative of acquisition and vindication' (p. 91).

When it comes to the book's themes of the diversity of twelfth-century historiography and of interactive textual communities, mention surely ought to have been made of Geffrei Gaimar. Not only was he a near-neighbour of the abbey when writing a history of the English in Old French based on a version of the Anglo-Saxon Chronicle that might have been the same one used at Peterborough, he was also working at the same time as the 'Second Continuator'. Reference to Hugh Thomas's discussion of language and identity in his The English and the Normans would certainly have been helpful to the book's argument. That some themes might have been developed further is ultimately to say that Malasree Home has made an important contribution that will be valued by all who wish to understand England's history over a centuries-long period.

University of East Anglia

DAVID BATES

\section{Deeds of the Bishops of Cambrai from the Late Empire to the Early Eleventh Century: Translation and Commentary. Edited by Bernard S. Bachrach, David S. Bachrach, and Michael Lesse. Routledge. 2018. xviii + 255pp. £95.00. \\ Medieval Flanders represents an extraordinarily vibrant region and crossroads in the history of medieval Europe. Recently it has received a great deal of}


scholarly attention from scholars such as Nicholas, Vanderputten and Oksanen. Consequently, it is very welcome to have a translation of this central source, which will serve to open up the subject to a broader audience, while supplementing existing texts in translation such as the famous The Murder of Charles the Good.

The book opens with a strong and succinct introduction, laying out the background and origins of the dioceses of Cambrai. Situated precariously between the kingdom of France and the German Empire, Cambrai's bishop had to perform a delicate balancing act between these two powerful neighbours, both of whom could claim varying degrees of authority over the diocese. This front matter goes on to discuss: the career of Bishop Gerard I of Cambrai, who commissioned this work in the mid 1020s; the two authors who wrote the chronicle's three books (about whom little is known); the dates of composition for these three books; and the chronicle's key themes and literary approach.

In structure the chronicle's first book covers the history of the diocese from the late classical period through to the year 1012. The second offers an interesting gazetteer of religious houses within the bishop of Cambrai's sphere of influence. The third then covers the early history of Gerard's pontificate, up to the year 1024. Like so many medieval texts, the editors conclude that the Deeds of the Bishops of Cambrai probably was not intended to be read as a single flowing narrative but rather to serve as a repository of knowledge from which information could be drawn.

In content, the Deeds of the Bishops of Cambrai is an enormously rich text covering many core research themes for the study of Flanders and indeed medieval Europe as a whole. These include the bishops' long-standing struggles with local disruptive noblemen and their sustained endeavour to maintain the peace. Strikingly, however, Bishop Gerard is shown to have been critical of the Peace and Truce of God movement, which - as he apparently believed - usurped the traditional role of secular rulers. Another notable quality to this text is its view on the much-contested issue of the investiture of clerics. The authors repeatedly reiterate the view that this prerogative lay with the king - fighting talk, even in the early decades of the eleventh century! The third book also contains Bishop Gerhard's famous account of the three 'orders' of society, made up of fighters, farmers and those who pray; a vital source within the historiography surrounding the structure of medieval European society.

Alongside these more internal affairs, there are also reports of invasion and war with external powers. The first book contains references to incursions by Northmen and there is a single reference to the emperor Otto II's disastrous campaign against Muslim forces in southern Italy in 982. Perhaps of greatest interest on this topic, however, is the detailed account of the Hungarians' assault upon Cambrai in 954. This event is described in considerable detail and, quite apart from the bare fact that the Hungarians were able to stage so audacious a strike so far from their homelands, many details are supplied reflecting contemporary perceptions of their culture and warcraft.

As one might expect, there is also a great deal of discussion here on the themes of spirituality and religious practice. There is one particularly memorable moral tale concerning God's justice. In this story, a man who was compelled to fight a judicial duel called upon God and St Vaast for aid. Then, equipped only with a pilgrim's scrip and staff, he faced his opponent only to be protected when God sent a cloud to obscure the battlefield. The synthesis in this case of the symbols 
of pilgrimage with an act of violence is perhaps particularly striking given the emerging contemporary ideas surrounding the concept of religious violence.

Another tale discussing themes of violence, relics and spirituality can be found in the third book where a lustful man who had slept with a nun attempted to use a brooch containing relics to protect him in battle. In the ensuing combat the relics protected him for a time, until they suddenly burst through his clothing and hauberk and flung themselves onto a white stone nearby. Many other such colourful moralizing tales are found in this source, shedding light on contemporary mentalities.

Overall, this text is an excellent addition to existing translations both for medieval Flanders and for the medieval Church. It also provides a wealth of further material on themes of economic life, warfare, local politics and Church organization. The text is supplemented effectively by maps, genealogical charts and also by comprehensive references. I have no doubt that it will be much appreciated by students and scholars alike.

Nottingham Trent University

NICHOLAS MORTON

Trustworthy Men: How Inequality and Faith made the Medieval Church. By Ian Forrest. Princeton University Press. 2018. xvi + 502pp. £35.00.

Ambitious, complex, challenging and provocative, this book is a stimulating and significant contribution to analysis of the social and ecclesiastical history of late medieval England. Based on intense examination of an extensive range of primary sources and secondary material, and combining subtle theoretical argument with broad empirical work, it is certainly a volume to be welcomed. It will have a lasting impact.

Ian Forrest's starting point is a single adjectival phrase, widely encountered in administrative records of the medieval Church: the description of some among the laity (almost always men) as 'fide dignus' - the 'trustworthy' of the title. Investigation of the term's meaning and import, and of the lay agency which follows from integrating these 'trustworthy men' into the investigative or 'inquisitorial' mechanisms of low-level (essentially parochial) actions within the Church, underpins an ambitious and laudable aim to develop 'a new sort of institutional history, one that could be summed up in the phrase "a social church" (p. 4). The goal may not be entirely new, but Forrest's approach certainly is.

The book comprises four distinct parts (each comprising a short introduction with subsequent chapters), building steadily towards a culmination oft-signalled en route. The first three parts contain three chapters each; the last has five. After a brief and forceful introduction, setting out the volume's aspirations, Part I offers a wide-ranging consideration of 'Late Medieval Cultures of Trust', with Forrest at his most theoretical. Successive chapters seek to penetrate mentalities of 'Theology: Belief in God' (chapter 1), 'Law and Agreements: A World Made from Promises' (chapter 2) and 'Identity and Emotion: Faith in the Heart' (chapter 3). Part II turns to 'Identifying the Trustworthy Men', locating 'trustworthiness' within a long-term social and institutional setting. From an initial broad analysis of 'The Emergence of the Trustworthy Men' 
over the twelfth to early fourteenth centuries (chapter 4), the discussion then narrows down. Chapter 5 examines the diocesan context, as 'Bishops Describe Trustworthiness', before drilling down (in chapter 6) to 'Very Local Elites'. Those (lay and sub-seigneurial) elites are examined more closely in Part III, which deals with 'Trustworthiness and Inequality in the Parish'. Chapter 7 considers whether these men really were 'Representing the Community?', offering statistical analysis of selected local elites. Chapter 8 analyses contextual issues of 'Time, Place, and the Limits to Trustworthy Status'. Perhaps surprisingly short, chapter 9 then goes 'Face-to-Face with the Trustworthy Men', assessing how the status of being 'trustworthy' played out in the social (notably gendered) realities of a localized community and 'what it was like to live alongside those men elevated above mere faithfulness and called fidedigni by the church' (p. 221).

The perspective and argumentative thrust changes in Part IV, using the preceding reconstruction to argue about 'Bishops and a Church built on Inequality and Faith, 1250-1500'. Opening (chapter 10) with a discussion of 'Practical Epistemology' (less theoretically oriented than its title might suggest), it then considers financial matters (chapter 11: 'Other People's Money'), 'The Material Church' (chapter 12), and the 'Subtle Judgements' (chapter 13) reflected in the relations between the trustworthy and the institutional Church. Chapter 14 sums up the presentation of 'The Church Built on Trust' before a brief conclusion brings things to a close.

That skeletal summary cannot fully reflect the volume's overall scope and content, or convey its significance. Nor can a review adequately respond to its arguments. Arguably, the book requires debate rather than review, and will provoke mixed responses. The social analysis of intra-parochial relationships seems fairly uncontentious, although being mainly rural its extension to towns may be less easy. The main difficulties perhaps arise as the argument extends beyond the overlaps of multiple local communities to posit a model of ecclesiastical power relations centred on episcopal authority and a deliberate policy of power-building. Arguably, this imposes an inappropriately top-down and monolithic view of episcopal power within a diocesan context, and oversimplifies the Church's structure. Paradoxically, much of the key evidence used to recreate the social histories derives from non-episcopal contexts, peculiar jurisdictions where the bishop's writ had limited currency, and which might indeed resist episcopal intervention as unwarranted interference. Homing in on a specific phrase in limited contexts carries the risk of developing a distorted analysis: the assertion (p. 241) that 'the English episcopacy showed especial affection for the term [i.e. fide dignus] and for the role [of being 'a trustworthy man']' is problematic. It elevates the citations of 'trustworthy' in some contexts (diocesan investigative mandates, visitations, and in other parochial contexts) above its use elsewhere; yet once isolated as important, it becomes fairly widely noticeable, regularly used by others. Intriguingly, although its full investigation is not central to the basic argumentative thrust, there is no comparative discussion of clerical 'trustworthiness', equally critical in many of the parochial investigations that Forrest highlights. The fundamental question is posed at a relatively early point (p. 123): 'Was this [emphasis on 'trustworthiness'] just a hollow rhetoric?' Or, to go further, was it merely a routinized bureaucratic formula? Forrest rebuts the question, but cannot fully refute it. It may then linger as a nagging and unresolved problem. 
Ultimately, the book seems to present a paradox. Despite the criticisms, its overall value and importance are undeniable. Penetrating, insightful, nuanced and demanding, it tears down the ring-fence between 'parish studies' and 'social and economic history', undermining some of the rosier depictions of parish life by demonstrating that 'the communalism of parish life did not mean egalitarianism' and stressing the importance of 'meaningful inequalities' (p. 129). Yet, like all historical scholarship, it faces the challenge inherent in its own production: as testimony, as reconstruction, how 'trustworthy' is it? The argument is undeniably persuasive, and will certainly convince, or be taken on trust by, many readers. (Regrettably, the book uses endnotes, not footnotes: that, with the condensed intensity of Forrest's scholarship, limits the practicalities of readerly debate with the author.) Yet, critically, the coupling joining the parochial social analysis to the diocesan governance structures may be weaker than asserted. The reader should perhaps approach the book with caution, ready to be persuaded but prepared to digest and assess the arguments critically, and then actively decide whether it does all add up. Getting that far is a rewarding and thought-provoking journey.

University of Birmingham

R. N. SWANSON

\section{The Letter Collections of Nicholas of Clairvaux. Edited and translated by} Lena Wahlgren-Smith. Oxford Medieval Texts. Oxford University Press. 2018. xcviii + 325pp. £95.00.

Nicholas of Clairvaux, dubbed here the 'black sheep' of the Cistercian Order, is a very interesting character and this critical edition and translation of his letters represents a valuable source both for mid-twelfth-century monasticism and for a wide range of related topics. This collection contains sixty letters (in both critical editions and translations) drawn from his two main letter collections, defined here as Nicholas's 'Clairvaux collection' and his much shorter 'Champagne collection'.

Nicholas himself had a very turbulent career (at least by monastic standards). He originally arrived at Clairvaux in $c .1146$ as a runaway monk, having fled from his former house at Montiéramey with a small group of like-minded fellows. Indeed, a good number of his early letters deal with the scandal caused by this deed and it is interesting to see in these texts how he positions himself and his actions in such a way as to quell - or attempt to quell - the outrage he provoked, whilst making it very clear that he has no intention of returning to his former house.

Nicholas then rose to become Bernard of Clairvaux's secretary and many of the letters contained in this collection were written on his master's behalf. His ascent to prominence was evidently swift because he soon became embroiled with the preparations for the Second Crusade, which was launched soon after he reached Clairvaux. Working alongside Bernard of Clairvaux, he acquired many friends in high places and a sizeable portion of his letters can be read as an object lesson on how medieval people 'won friends and influenced people'. His careful use of flattery coupled with his evident desire to make himself useful seems to have won approval among many leading churchmen, including several popes. Nicholas's fall from grace occurred as precipitously as his rise. In 1152, he was 
caught falsifying letters and was expelled from Clairvaux. This did not end his career, however, and he reappeared in 1160/1 as the prior of St-Jean-en-Châtel in Troyes. He died in the mid-1170s.

In structure, this work opens with a detailed introduction, which provides a thorough survey of Nicholas's life, his other works (sermons, exegetical commentaries, etc.), as well as his style and influences. As Wahlgren-Smith observes, his letters are thick with biblical allusions and it seems that he, like his master, was so deeply immersed in biblical language that it is difficult at times to see where the citations end and Nicholas's own words begin. The letters contained here are not evenly spread across his life but occur in chronological clusters with significant gaps in between. The work concludes with a series of appendices in which the editor provides helpful context for several of the key conversations found in these collections, including those surrounding the Second Crusade, the career of Bishop John of Alet and his endeavour to move his see from Alet to St-Malo, and Nicholas's correspondence with the famous theologian, Peter of Celle.

In content, the letters provide useful material on a fair range of topics, beyond Nicholas's own career and interests (which nonetheless feature prominently). Scholars interested in crusading will find much to interest them in letters discussing the Second Crusade. Chief among these is a letter written to Count Conan III of Britany, which is replete with terms and ideas redolent of the crusading movement of that era. Nicholas also wrote a letter of introduction for Theobald, son of the count of Champagne, to Emperor Manuel Comnenus, and there is also a fascinating reference to King David of Scotland's plans (never fulfilled) to join the campaign. In addition, the collection contains a possibly rather cheeky letter where Nicholas asks Arnold of Vienna (Conrad III's chancellor) to hand over to Clairvaux his magnificent library, citing in return the spiritual rewards he would receive on crusade for so doing.

Other important themes include some close insights into the ongoing 'business' of Clairvaux, its policies and relationships with other important contemporary figures. Scholars familiar with the exegetical ideas and tropes propagated by leading Cistercian authors will find much to interest them here, including a detailed and rather militant description of the abbey of Clairvaux, stressing its inhabitants' warlike credentials in their spiritual struggle for salvation.

There is rather less detailed commentary on specific biblical verses, questions or theological issues than one might expect from so important a churchmen. Certainly, and despite his sustained use of biblical material and long-winded circumlocutions, many of Nicholas's letters actually resemble 'letters' in purpose, rather than the mini-sermons masquerading as letters common to many other letter writers of his era. There are, however, exceptions, including his correspondence with Peter of Celle where, among other topics, he offers a range of thoughtful insights on the theology of the Trinity.

Overall, The Letter Collections of Nicholas of Clairvaux will sit very comfortably alongside Oxford Medieval Texts' other major critical editions/translations of letter collections from authors such as John of Salisbury, Thomas Becket and Peter of Celle. It stands as an extremely valuable contribution to the available material covering the circles of correspondence surrounding such mid/late twelfth-century authors. In particular, the provision of so detailed and carefully 
prepared an introduction helps to place this collection in a deeper context, representing a real advance on existing scholarship, whilst offering background on a fascinating individual who evidently had a very colourful career.

Nottingham Trent University

NICHOLAS MORTON

Thirteenth Century England XVI: Proceedings of the Cambridge Conference, 2015. Edited by Andrew M. Spencer and Carl Watkins. Boydell. 2017. xiii + 206pp. $£ 75.00$.

As with those themed parties, once so fashionable, there comes a point, after more than a dozen such events, when the organizers risk either repetition or the ridiculous. What an inspired choice, therefore, for the sixteenth of these Thirteenth Century England conferences to be organized around the theme of 'Uncertainty'. Amanda Power opens proceedings with a penetrating analysis of ecclesiastical reform. Since the Church itself could only sporadically hope to restore a prelapsarian state of inspiration, the clergy were confronted with the problem of how to prolong the upwards curve before mankind's inevitable plunge back into doubt and despair. In short, once the vineyard had been cleared of the briars of error or decadence, how was certainty to be institutionalized? The definition of dogma, the creation of new religious orders (the friars) and the punishment of disobedience or heresy might all be enlisted to such ends, as in the Lateran Council of 1215. So might the idea of 'redemptive government', central to the programme of Louis IX. This essay, like the best of its kind, raises as many questions as it answers. Why, for example, have modern commentators made so much of the sacrament of baptism but comparatively so little of the rite of confirmation? Did frustration at the repeated failures of the Church (and especially the papacy) to maintain the momentum of reform contribute to the upsurge of apocalypticism that swept Europe from the 1230s onwards, not least in England, a realm rich in reforming programmes whose failure was blamed upon the corruption of hierarchies both of Church and state?

Power's essay is followed by two others equally thought-provoking. In the first, Emily Corran investigates the origins of casuistry, looking to the confessors' manuals in which the confessor was invited to choose between two or more nonideal courses of action. Her inclination is to seek the origin of such debates in the practicalities of more frequent lay confession, after 1215. Origins might just as easily be sought in the semi-fictionalized debates of the schools: paring causes from effects in ways familiar from Abelard onwards. What remains clear, nonetheless, is that this was an age not of certainty but of anxiety and troubled conscience. As Corran comes close to formulating it: to legislate may be divine, but to equivocate is truly human. In much the same vein, Felicity Hill points out the paradoxes inherent in excommunication: a sentence that might be interpreted both as punishment (threatening if not guaranteeing damnation) and as medicinal prompt to repentance. For all of the legalism applied to such sentences, evident from the 1240s onwards, an insistence on correct procedures tended to create not certainty but multiplying opportunities for error and doubt.

After three such truly splendid essays, the fancy dress of uncertainty is to a large extent cast aside, leaving merely a lingering sense of ambiguity. 
Thus Frédérique Lachaud explores the thought-world of Thomas of Docking, author of close on a million words of still-unpublished commentary. Although prejudiced against alien clergy, Lachaud demonstrates, Docking can by no means be easily stereotyped as a supporter of the reforms of the 1260s. Like John of Salisbury before him, he seems to emphasize obedience even in the face of injustice, leaving retribution to God alone. Expanding this theme, Andrew Spencer considers the deposition of kings. For all its exposition of modern ruler-theory, this is an essay stronger on clarity than originality. It will be of considerable use to undergraduates. Even so, neither Thomas Tout nor Bertie Wilkinson would have been troubled by its conclusions. Adrian Jobson strives after something more original, theorizing over the particular risks of rebellion against English kings. As in other such taxonomies, the line between originality and banality here remains perilously thin.

Two essays, by Jessica Nelson and Alice Taylor, deal with Scottish facts rather than English abstractions: Nelson with King John's attempts to forestall a Franco-Scots marriage alliance by demanding the daughters of King William as hostages, Taylor with the extraordinary efficiency with which upwards of thirty English monasteries answered the call by Edward I for chronicle evidence of Scotland's relations with the English crown. What is most noticeable among these returns is the focus on the same, relatively narrow span of events and chronology; hence the laconic endorsement of so many of them (as potentially of so many conference proceedings) 'nichil novum'. Of the monasteries questioned, only Huntingdon, with its close connections to the kings of Scotland, dared contradict the dominant narrative, proclaiming a degree of Scots independence denied elsewhere. Less confidently, Lucy Hennings addresses the paradox that was Simon de Montfort, alien French leader of anti-alien rhetoric. There are mistranslations and mistakes here, not least the identification of Peter des Roches as a native of Normandy. Finally, Kenneth Duggan discusses the use of 'hue' and 'clamour', terms that covered a wide variety of meanings from mere outcry to the summoning of the county posse. As Duggan reveals, although provincial society remained essentially self-policed, control over hue and clamour allowed for a degree of state interference in processes that might otherwise have remained locally autonomous. As in Hill's essay on excommunication, what we find here is process exploited as a tool of centralized control, not primarily as an instrument either of efficiency or of justice. Those of us dragged into an age of tick-boxes and form-filling should be under no illusion: an obsession with process, then as now, is unlikely to please any constituency, except those who invent routine and the lawyers who, jackal-like, shadow the legislators.

University of East Anglia

NICHOLAS VINCENT

\section{'The Right Ordering of Souls': The Parish of All Saints' Bristol on the Eve of the Reformation. By Clive Burgess. Boydell. 2018. xx + 463pp. $£ 60.00$.}

This long-awaited monograph builds on years of painstaking archival research, numerous essays and the author's three-volume edition The PreReformation Records of All Saints (1995-2004). Ever since his seminal article on the 'Increase of Divine Service', which appeared in 1985, Clive Burgess 
has drawn on the parish's remarkable source survival - encompassing, among others, churchwardens' and (rare) chantry accounts, deeds, wills and a multigenre compilation known as the 'Church Book' - to reconstruct the religious and related secular activities of a small city-centre community of around 200 souls during the fifteenth and early sixteenth centuries. In a comprehensive study, he presents us with a most impressive panorama of late medieval spirituality and organizational capacity which ranges from the adoption of period trends - set by the crown, enterprising bishops and collegiate foundations - right down to the nitty-gritty of maintaining the properties bequeathed in return for bespoke commemoration. As a 'thick-description' of pre-Reformation parish life, it can be set alongside Eamon Duffy's Voices of Morebath.

Just a few of the study's rich findings shall be highlighted here. Far from pointing to greater individualization, chantries constituted an 'organic part of the parish' (p. 246), benefiting it through the priests' involvement in sophisticated musical provision and the passing on of vestments and equipment once their funding had ended. The same can be said for fraternities, here particularly the clerical guild of the Kalendars, whose members participated in the cure of souls, ran a library and guided individuals in their pious donations. Rather than indicating punctual initiatives, the late medieval rebuilding and embellishment of the church (a small edifice with partly overbuilt aisles boxed in by surrounding houses) points to a shared vision driven by families such as the Halleways, Chestres and Spicers, notably a succession of entrepreneurial widows whose intercessory and charitable arrangements went well beyond those of their husbands. Key decisions were taken by an assembly of householders, with strategic leadership exercised by a group of prominent 'masters' and day-to-day administration in the hands of churchwardens. Throughout, Burgess emphasizes the collaborative spirit of laity and clergy, city and parish, individuals and groups, working towards a liturgical regime arguably comparable to that of King's College, Cambridge (p. 405). Tensions were few and far between: when Richard Haddon, an exuberantly generous benefactor responsible for the rebuilding of the north aisle, reclaimed some endowments at a time of financial difficulties, the parishioners all but wrote him out of their bede roll (p. 182) and seized the next opportune moment to recover what they considered rightfully 'theirs'. Time and again, the author capitalizes on the existence of complementary sources, e.g. by using benefaction lists to uncover donations not mentioned in wills or accounts. The argument is supported with helpful plans of the church's location and layout, photographs, a glossary and index, as well as appendices of documentary extracts.

All Saints', of course, was only one of thousands of English parishes and the question of its 'typicality' arises repeatedly. Burgess casts some spotlights on other Bristol, London and provincial communities, finding just about enough similarities to propose an affirmative answer. As for leadership and inspiration, he tends to look up the social scale, to masters, guild priors, incumbents and members of the city government, returning to their main contributions again and again. While acknowledged, the skills and initiatives of lowlier members of All Saints' are given less weight, as are possible secular factors - such as civic virtue, lay assertion, local government priorities - compared to religious incentives. The author's warnings about source imperfections, even in such a well-documented context, contrasts with at times bold claims about the roles of individuals and 
their apparent motives. Methodologically, readers encounter passionate pleas for qualitative approaches to medieval records, but even Burgess cannot do without the odd piece of quantification (pp. 216, 237, 372).

Overall, this is a most welcome exemplification of 'what it was like' to be a late medieval parishioner, written by one of the pathbreakers of revisionist interpretations of pre-Reformation religion, albeit one with a few interpretative preferences and a distinctly urban perspective.

University of Warwick

BEAT KÜMIN

Religion, Time and Memorial Culture in Late Medieval Ripon. By Stephen Werronen. Royal Historial Society Studies in History. 2017. viii + 204 pp. $£ 50.00$.

Since Anglo-Saxon times the name of St Wilfrid has been inextricably linked with Ripon, a town at the edge of the Yorkshire dales. Wilfrid was one of the leading figures in the diocesan and religious development of the Anglo-Saxon Church in the seventh century, contributing richly to the religious life and the episcopate, promoting Roman discipline and ecclesiastical practice. His affinity with Roman heritage was crowned with success at the synod of Whitby in 664. He was the abbot of Ripon at the invitation of the sub-king Alcfrith and was credited with the introduction of the Rule of St Benedict. His life was narrated by Bede in his Ecclesiastical History and by Eddius Stephanus, who dwells on Wilfrid's activities in Ripon, where he built a church in dressed stone with side aisles. He himself presided over the dedication of that church to St Peter, the prince of the apostles. At his death in 709, Wilfrid was laid to rest in the church which he had built and consecrated. His cult spread from Yorkshire to other parts of the Northumbrian Church and English Church. He became a leading saint of the northern Church. The archbishops of York promoted his cult in the northern province, responding strongly to Canterbury's claims to have removed his relics to the heart of the southern province. They fostered the rebuilding of Ripon Minster and the translation of his relics to a new shrine at Christmas 1224. A later vita was composed by Peter of Blois, whose text has been partially recovered in a liturgical manuscript from late medieval Ripon. Lessons for the nativity of the saint were drawn from the earlier writings, emphasizing his apostolic credentials. His cult and his continuing influence on ecclesiastical life at Ripon form the basis of this handsome new monograph, which focuses upon the extensive parish in the later Middle Ages.

The five chapters of this monograph address St Wilfrid, the patron of the Minster and the parish; the Minster clergy; the Minster and its parishioners, the living; the liturgical year of the Minster and its parish; the Minster and its parishioners, the deceased. The cult of St Wilfrid drew visitors and pilgrims to the town of Ripon, which held its own fairs in the Middle Ages to commemorate his three feasts, uniting the spiritual and the material. Ripon was one of the most important towns in the county along with Pontefract, Doncaster, Whitby and Selby, but its population was smaller than the larger city and towns of York, Beverley, Hull and Scarborough. The parish of Ripon comprised more than 
eighty square miles and was served by a number of rural chapels in the fourteenth and fifteenth centuries; they are identified by the third map and include Sawley, Monkton, Nunwick, Dishforth, Hewick Bridge and Studley (p. 95). The town was linked to York by a waterway and there were commercial and trading links between the two centres. While there was no dearth of tradesmen in Ripon, more specialized skills and luxury goods were available in York. There was a weekly market in the town and two annual fairs, which were especially important for the marketing of livestock. The production of cloth flourished in the area.

The saint's spiritual capital in north Yorkshire was invested, as Stephen Werronen explains, in the Minster's canons, who adjudicated in cases of breaches of ecclesiastical discipline and conduct. The ecclesiastical court arbitrated in disputes about the area and in violations of the religious code, such as failing to observe the penitential season of Lent and the various feasts of the patron saint. Fountains Abbey lay within the parochial boundaries and, despite the magnetism of the cloister, monks were on occasion engaged to celebrate Masses in the rural chapels of Ripon Minster. In 1474 the chapter of the Minster entered an agreement with the chapter of Fountains Abbey for one of the monks to celebrate Masses at Aldfield, a village three miles from the monastery. The cult of Wilfrid flourished in that village.

The fabric wardens of the Minster often required the raw materials for building the Minster. William Wright was a timber merchant who sold timber for the fabric in 1391 and eight years later he built the new roodloft. The town's plumbers also supplied lead for the Minster. In the last decades of the fourteenth century the Minster's chief suppliers of lead and plumbers were the Bettys family of Sawley. From time to time they had need of glaziers and masons. Such specialized labour was found in the larger centres of population, such as the bell-founders and clockmakers of York. For building projects the Minster turned to York once again to hire a larger number of masons together with a master mason to draw up the design of the new building. In 1520 Christopher Scune was employed as the master mason; the carpenters were supervised by William Carver, alias Bromfleet. Vestiges of the programme of wall painting within the Minster survive on the north wall of the chapel of the Assumption (pp. 70-1, 85). The chantries within the Minster are described, as are the various liturgies celebrated in such chapels, especially on the anniversaries of the donors and their families. The fragment of an obit book yields information about benefactors of the Minster and the celebration of the anniversary of their death. Similarly, the misercords were carved in the middle of the fifteenth century, possibly at Ripon or its vicinity. This artistic source is introduced briefly at the beginning of chapter 2 (p. 40). It is a pity that the misericords are not described in some detail because they would have complemented the liturgical and agricultural rhythm of the year.

One of the strengths of this monograph is the way in which the author shows the symmetry between the rhythm of the liturgical year, with its cycle of feasts, and the calendar. The feast of the invention of the Holy Cross on 3 May had a parallel in the agricultural calendar in March, probably around the feast of the Annunciation, when the lambing season began. The fourth map locates the important manors surrounding Ripon. The archbishops of York permitted many of these nobles to have Masses celebrated in their domestic chapels; neighbours were also invited to attend the chapel. These licences, however, required those who attended such chapels to be present at the mother church on specific occasions, 
such as Sundays or feasts associated with St Wilfrid. No mention was made of the suffragan bishops in the diocese of York, John Kegill, OFM, and Richard Messing, O.Carm., who were appointed to the hospital of St John at Ripon in the 1450s and 1460s. As well as celebrating Mass in the hospital, it is probable that they had some role in the various liturgical celebrations of Wilfrid's feast days. This is a pleasing study of the parish of Ripon and its illustrious shrine, depicting the contours of the liturgical year and its companion in the movement of the seasons.

St Edmund's College, Cambridge

MICHAEL ROBSON

The Hundred Years War in Literature, 1337-1600. By Joanna Bellis. Boydell. 2016. xii +300 pp. $£ 60.00$.

Traditionally, the Hundred Years War has formed the foundation stone of late medieval Europe's military history: the size and effectiveness of the forces involved, the tactics employed, the weapons used, the leadership given are all aspects of war which, for a long time, dominated the subject. Understandably, however, during the past half-century and more the subject has moved on, with the social and economic effects of conflict coming to dominate research. Who, for instance, fought in the English armies which went to France in the late fourteenth and fifteenth centuries? Thanks to systematic research we now have a pretty good idea of who these men were, and what a military 'career' might involve. 'Literary' sources have much to teach us. Chronicles are important both for the information they convey and for the tone of the language used by their authors to express their feelings regarding the events which they describe. Some texts are clearly little more than propaganda, intended to influence opinion. Nor should it be forgotten that contemporary poetry (verse may be a better word) and songs have much to tell us about popular feeling and what motivated men to go to war in support of king and country. While being chiefly recorders of events and attitudes, chronicles frequently have more to tell than may at first appear, often as the disseminators of political messages which contemporaries would have understood.

It is such messages, particularly those concerning events and developments occurring in the period $c .1350$ to $c .1600$, which have caused later students of the period to either play down or fail to understand certain cultural aspects or byproducts of the Hundred Years War. Too easily forgotten have been the cultural, above all the linguistic, developments which arose from the long conflict. When, in 1346, it was reported in parliament that English soldiers had found evidence in Caen purporting to show that the French king was planning an expedition across the Channel 'a destruire et anientier tote la nacion et la lange Engleys' ('to destroy and ruin the whole English nation and language'), the irony that the formal record should have been written in French, rather than in English, should cause us no surprise since French was still in use as the day-to-day language of government. And not only at the court: Dr Bellis writes that French 'saturated' the language employed by many groups in late medieval English society. Pace Chaucer, there is little evidence in the fourteenth century of an emotional link between the English language and a sense of national identity. Only under Henry $\mathrm{V}$ would that advance begin to be made. By the mid-sixteenth century the English 
language was becoming the benchmark of any definition of the English nation, as well as the means of giving it both life and a soul.

As we all know, the war was fought on both land and sea. To these scenarios, the author adds a third: 'on paper'. It is this theatre of war which is her particular concern. She argues convincingly that vernacular poetry was developed to influence opinion, to demoralize the enemy by pouring scorn upon him, and to applaud the actions carried out by Englishmen which showed the enemy in an unfavourable light, both morally and militarily. In verses which began 'Remembers ye of Brugges ...' the men of Bruges, Ghent and Picardy were all on the receiving end of English mockery for failing to come to the rescue of Calais in 1436, since (it was alleged) they feared an English force led by the duke of Gloucester which had only just been assembled in London; or so the compiler of the Brut would have had his readers believe. Verses and chronicles were used to underline English superiority in war, thus creating a thematic background which could unite the country against physical threats from abroad. In this way the conflict waged against cowardly and slippery Frenchmen and their treacherous Burgundian allies encouraged Englishmen to see themselves as a nation, united by their language, history and successes in war. 'To compare with Englisshmen, ye [Flemings] aught to be ashamed!'

Historians should be glad to have it pointed out that the use and influence of the French language in England, particularly in cultural circles, was still alive at the end of the sixteenth century. How widely has it been appreciated that one important consequence of the old Anglo-French rivalry (still showing signs of life in the sixteenth century) was the fear expressed by many Englishmen that their language was being contaminated by the increasing use of French words in the everyday parlance of many Englishmen? So was born what came to be known as the 'Inkhorn Controversy', which reflected concern regarding the growing use of foreign words and phrases 'to powder ... with overseas language' England's native tongue at a time of important development. Such was the controversy to which Shakespeare, among others, would refer. In Henry VI, part 2, he described the clerk of Chartham being condemned to death for being both literate and numerate: 'hang him with his pen and inkhorn about his neck', urged Jack Cade, while a little later Lord Saye was condemned because 'he can speak French and therefore he is a traitor'. Could one who 'speaks with the tongue of an enemy be a good counsellor, or no?' Such a question reflected both a political conflict and a cultural war, too.

All this, and more, is contained in this interesting and cogently argued study. Not the least of its lessons is the one that historians should not be afraid to push the boundaries of what they regard as the 'proper' study of war. There is sometimes, as in this case, a lot to be learned from doing this. Having a sympathetic guide is, as always, a help. This is, without doubt, a 'helpful' book, which should be of interest to historians and students of literature alike.

University of Liverpool

CHRISTOPHER ALLMAND 


\section{Medievalism, Politics and Mass Media: Appropriating the Middle Ages in the Twenty-First Century. By Andrew B. R. Elliott. Boydell. 2017. x + 223pp. £30.00.}

On 16 July 2018, controversial atheist, sceptic and biologist Richard Dawkins posed for a picture in front of Winchester Cathedral and used the backdrop to tweet a racist statement comparing the bells of 'one of our great mediaeval cathedrals' to the 'aggressive-sounding' Muslim adhan. As of this writing (7 August 2018), this tweet has garnered 16,915 'Likes', 3,646 retweets and more than 10,000 comments (including one from the account 'Racism WatchDog', replying simply: 'WOOF').

I start this review with Twitter not simply for the populist appeal but for two reasons. Firstly, this is the context in which Andrew B. R. Elliott's 2017 Medievalism, Politics and Mass Media: Appropriating the Middle Ages in the Twenty-First Century sits. Secondly, this demonstrates very soundly many of the principles of Elliott's ideas: that the use of the medieval and medievalism through online mass media provides a platform through which many groups, particularly right-wing, white supremacists, racists, far-right and fascist outfits, present their ideas about Islam and Muslims that gain traction and large audiences, often through easily disseminated memes on closed loops. When the Middle Ages is emptied of historical meaning, 'medieval' is used without context to further the aims of an increasingly vocal far-right and fascist constituency through the mass media. In this context, Elliott's book moves from being very important to Very Important: mass-media medievalism has increased since the book went to press in 2016, seeing the 'medieval' become emptied and refilled with meaning divorced from history, rendering the past a place for appropriation.

Elliott works with what he calls 'banal medievalism', borrowing from Michael Billig's 'banal nationalism'. Banal medievalism is based in 'not the past but an absence of that past' (p. 19), a medieval specifically 'dislocat[ed] from history' which then has 'no specific, identifiable sign to which it is pointing' and so 'does not require any specific skills to decode it' (p. 23). Some of these uses feel more benign than others; for example, a data-gathering exercise of online banal medievalism from the week of 20-27 October 2012 includes examples such as a captured 600-pound-marlin 'going medieval' on a fishing vessel (p. 49). But even these examples, as Elliott's banal medievalism stresses, do not seek to clarify the present from the past but instead use the medieval as an empty signifier. The reference to the term 'medieval' in banal medievalism refers to anything 'not considered to be progressive and relentlessly forward-looking' (p. 72). This is what underlies the issues in the interconnected case studies which constitute the bulk of the monograph.

These case studies focus primarily on 'crusade/crusader' analogies and their extensions. Two intertwined chapters examine George W. Bush's and Osama bin Laden's uses of the same medievalism to demonize the other. The former begins with Bush's ill-advised and off-script reference to the War on Terror as a 'crusade' and the Bush PR team's banal medievalism to create division between 'us' and 'them', the 'medieval' and 'modern' East and West, and subsequent casting of the 'Crusade as Liberation' (pp. 78-105), relying on a Comtean idea of positivism and 'progress' from a medieval to a modern society, and echoing Elliott's definition of the banal medieval as seen as anti-progressive. Similarly, though, al Qaeda's '[use of] precisely the same rhetorical division into "us" and "them" in the decade 
previous to 9/11 resulted in the subsequent post-9/11 use of Bush's 'crusade gaffe' to 'position [the West] as Crusaders and al Qaeda as brave defenders' (pp. 108-9). Banal medievalism plays an unquestioned role in Islamophobia and racism, and these linked case studies further demonstrate how history, stripped of information, becomes a channel for conflicting and opposing appropriation.

Two further case studies offer equally integral and intersecting studies. The first explores Anders Behring Breivik's manifesto and its insistence on a new Templar order, a medievalism produced in a still-continuing, online 'closed loop of banal medievalism' (p. 153). This language of banal medievalism is also shared by far-right groups such as the English Defence League (EDL) and others. Elliott's examination brings to the fore the more significantly damaging aspects of these online closed loops to far-right rhetoric. Calling them the 'counterjihad filter bubble' (p. 173), Elliott demonstrates how these closed loops perpetuate confirmation bias as well as 'avoid[ing] encounters with contradictory material' (p. 171), all features which contribute to the shared political as well as medievalist language. The discussion of the banal medievalism of the EDL and its insistence on the 'medieval' Islam, highlighted in Tommy Robinson's 2011 Newsnight interview with Jeremy Paxman (pp. 162-4), is placed in contrast, ironically, to groups such as the Front National, Stormfront, British National Party, Traditional Britain Group and the EDL itself making links to white, panEuropean medieval origins as the basis of their approaches to white supremacy (pp. 176-81). This is particularly apt in demonstrating not only the danger of political medievalism in these contexts, but also the absolute divorce of banal medievalism from historical content.

The political climate in which Elliott wrote this book is still current. A final chapter, including the book's conclusions, brings the monograph right up to its own submission date in 2016 in analysing IS, the Middle Ages and mass media, and this is ongoing. Elliott rightly points out that the use of the medieval past has never been dislocated from modern discourse but that the newness in the twenty-first century is in the targets: largely Muslim and Middle Eastern since the "neomedievalism . . . "Clash of Civilisation" theory emerged in East/West relations' starting with the Bush Doctrine post-9/11 (p. 199). In this sense, Elliott poignantly notes, 'complex debates become transposed onto a simple dialectic between medievalism and modernism, and implicitly between neomedievalism and neoliberalism' (p. 199).

Elliott's work is thorough, excellently written and gives his readers, who should include students, medievalists, modernists, media experts, politicians and activists, a framework to understand the particular rhetoric of political medievalism in the ever-changing landscape of mass media. It is difficult to understate how crucial Elliott's monograph is on both the academic and the public levels.

University of Winchester

KATHERINE WEIKERT 


\section{Early Modern}

Fashioning the Early Modern: Dress, Textiles, and Innovation in Europe, 1500-1800. Edited by Evelyn Welch. Oxford University Press. 2017. xvi + 456pp. $£ 50.00$.

Fashioning the Early Modern is a celebration of collaboration. The product of the 'Fashioning the Early Modern: Creativity and Innovation in Europe 15001800 ' project funded by the Humanities in the European Research Area, its richness comes from its international perspective with the material culture of Denmark, Spain, Sweden and Greenland discussed alongside England, Italy and France. This breadth makes it an important English-language contribution to the historiography of European dress, uncovering international similarities and distinctive fashionable cultures. Fruitful collaboration between curators and university researchers, sharing knowledge and expertise in museums and universities across Europe, is evident and plays out in both the authorship of chapters and the 'Object in Focus' pieces. The authors' varied methodologies remind us that there is no single fashion history. Technical object analysis, economics, politics, society, culture, design, knowledge cultures and more are used to show that technology is not the only originator or catalyst of innovation.

Evelyn Welch's introduction provides a broad overview of European fashion cultures, giving the reader a grounding in key contexts including dress and morality and methods of dissemination of fashion knowledge. Part I, 'Innovation', considers the roles of institutions and social groups in creating fashion change. John Styles calls for a return to the conceptualization of fashion as 'a process of change' to counterbalance the multitude of material on fashion and identity. He shows how mercantilist and authoritarian innovations in seventeenth-century France were the roots of the modern cyclical fashion system. Giorgio Riello similarly emphasizes economic motivations by identifying the French state as a potentially restrictive force that supported innovation to keep French products competitive. Tools included regulation of product quality, legislation, state involvement in manufacture and responding to the market via privileges, legislation, funding and collecting information.

Amanda Wunder's chapter builds on these institutional approaches by putting politics at the heart of Spanish fashion change. Philip IV banned large men's ruffs, which were a symbol of the excess that had led to Spain's decline. Flat collars took the place of the ruff leading to the creation of the golilla to support the collar and hide embarrassing Adam's apples. In contrast, the guardainfanta, a farthingale, was banned for its immoral association with hiding pregnancy, but its suggestion of fertility led to the guardainfanta's illegal adoption by the royal household. Evelyn Welch and Juliet Claxton also highlight the creation of fashion innovations by the elite, whereby even items such as a cheap black silk string could be used to show off social connections and knowledge. Distinctive fashion cultures were also created lower down the social spectrum as Paula Hohti's research on middle 'class' Italian dress shows. Residents of cities that regulated dress through sumptuary laws developed their own style through considered combination of garments and accessories in fashionable materials, colours and embellishments. 
Part II, 'Reputation and Dissemination', is the longer section and examines the circulation of fashionable goods and knowledge and individual reputations. Corinne Thépaut-Cabasset focuses on François I. Gaultier and considers his reputation at the French court and in Paris, extensive international trade and large stock being key to his status as a leading French merchant and retailer. Lesley Ellis Miller identifies the elements that led to the success of Lyons silk manufacturers in the dissemination of information about products, quality, reliability and novelty of design. Lyons silk designers built their reputations through education, design innovation and artistry.

Maj Ringgaard covers nearly 300 hundred years of knitting and knitted garment fashions across all ranks, with innovations such as the purl stitch changing stocking construction and decoration. She emphasizes the continuation of hand knitting alongside use of the knitting frame and explains European differences in the rate of adoption of the frame through local protections, workforce resistance, and considerations of ease, speed, quality and the need to hand-finish frame-knitted garments.

Peter McNeil and Patrik Steorn show the symbiotic relationship between fashion and print. McNeil discusses print as a medium for sharing knowledge of dress and embroidery designs and also for inspiring design, with printed leathers used for fashionable gloves and figurines inspired by fashion plates and caricatures. Steorn identifies the same processes in Sweden, where Europeaninfluenced prints were created to launch Gustav III's reformed court dress and were exported across Europe. A focused study of the English caricature 'Ridiculous Taste', which mocked elite women's oversized hair, shows the shift of meanings in the Swedish context, which included symbolizing printers' freedom and moral concerns, and its use as a humorous design to rework in paint and embroidery.

Mikkel Venborg Pedersen and Peter Toft also contribute to discussion of the adoption and adaptation of imported goods. Venborg Pedersen explores how colonial trade influenced the domestic material culture of different ranks of Danish-Norwegian society, with some discussion of textiles. Toft uncovers the adoption of European goods traded by the Royal Greenlandic Trade Company in Inuit material culture. Women added decorations such as beads or ribbons to traditional dress while the cut, materials and design of European clothing had a greater influence on men's dress. Novelty and religious repurposing made European goods popular.

Objects in focus appear throughout the book, giving insights into surviving items. Those with detailed technical analysis of the object, an essential curatorial skill, are particularly valuable in providing vocabularies and models for object-led research.

Fashioning the Early Modern is a book that will introduce you to the 'little lettuce' ruff and challenge your ideas of innovation. It contains a breadth of European early modern fashion history that cannot be found in other volumes in English and will, one hopes, inspire future collaborations that continue to open out the world of fashion.

Royal College of Art

ALICE DOLAN 


\section{Carnal Knowledge: Regulating Sex in England 1470-1600. By Martin Ingram.} Cambridge University Press. 2017. xv + 465pp. £21.99.

This long book has been a labour of love. Martin Ingram's 1987 monograph on the church courts, sex and marriage between 1570 and 1640 has stood as a signal work in early modern social history for over three decades. Now he has followed this with a truly magisterial work on 1470-1600, which, despite much done by others on the subject in the meantime, he can claim with good reason 'is the first to examine the issues systematically and in depth'. He modestly calls it 'a meditative expansion on a few characteristically penetrating paragraphs' by his mentor Keith Thomas about the 1650 Act of Adultery, published in 1978. What an expansion! Ingram now ranges over London, town and country before 1530 and during the Reformation, reaching, as this book meets up with his earlier work, the Elizabethan bridewell and a review of regulating sex in Elizabeth's reign.

The introductory pages on the issues of marriage, fame and shame in this period are revelatory. Sexual activity in all its guises, and the punishment of sex by penance and myriad kinds of public shame, then informs the book throughout, through close chronological analysis. What a complicated story this turns out to be. For local conditions and jurisdictional preferences were supreme in this matter. Where did most Tudor sex take place? Ingram shows that London with its famous Southwark stews was predictably the centre of the national sex trade. So bawdry, the composite term for procuring and facilitating sex, is absolutely at the very centre of his account. But there was plenty of bawdry in provincial towns as well. Ingram has over sixty references in his index to this composite term for obscene talk, language and activity to which Tudor magistrates were so attached.

A strength of the book lies in Ingram's meticulous research in carefully chosen local archives. Sections on pre-Reformation Leicester, Salisbury, Nottingham and Colchester are particularly striking. Turning to the period after 1558, with the title 'towards the new Jerusalem' and in considering the reformed church courts, Ingram chooses to focus on the archdeaconries of Leicester and Chichester. One might remark that the far west, East Anglia and the north largely escape his penetrating lens. But what could he do? Half a working lifetime, amidst a heavy load of teaching in Oxford, went into this magnum opus. Ingram surely made the right choices in selecting the archives he would use and, over and over again, they show that how sex was enacted and how it was punished varied enormously from place to place on his canvas.

One of the very prominent findings of this book is that late medieval and Tudor sex outside marriage was as rife among the gentry and middling groups as among the poor. The reason is simple and emerges frequently in Ingram's account. The gentry had massive opportunities to seduce young girls at home, in a society where there was no systematic control of personal behaviour in the household. He shows gentry, sometimes caught when they were at their most blatant, but also often avoiding censure and punishment. Corporal punishment for adultery or fornication, it emerges, was much fiercer between 1470 and 1558 than after the Reformation. This is a general aspect of early modern social history that has not been much stressed, for it takes the very detailed work on a long period that Ingram has done to bring it out. We all know from parliamentary debates how keen the gentry were to escape a whipping themselves, especially in public. Ingram shrewdly makes the point that the elaboration of the Tudor poor law, associating 
physical punishment, especially carting, with keeping the poor in their place, may have brought home to landed men that one law for them and another for the poor was a very sound maxim.

Ingram notes that the early Elizabethan regime had some inspiring examples to follow, notably Scotland. Whipping as an element in ecclesiastical penance, his book shows fully and convincingly, had been commonplace in the late Middle Ages. Yet, while the diocesan and archdeaconry system of visitation flourished after 1558, 'corporal punishment by the ordinary Church courts rapidly withered away', in the uncongenial legal climate of Elizabeth's reign. There were new expedients to shame fornicators eagerly taken up in some courts. In 1568, in the godly stronghold of Ashby de la Zouche, William Tette had to stand in the porch when the people came in 'being naked saving one linen cloth to hide his secrets, covered with a hair cloth and his head sprinkled with ashes'. While the minister read the homily of adultery, he, standing by 'with a white rod in his hand', then had to announce his penitence, asking the congregation to pray for him. As Ingram notes, all this, the dramatic use of space to separate the sinner then his reintegration with the congregation, was carefully orchestrated. His account shows how the Elizabethan regime showed 'a lively interest both in the bridling of sexual sin and the use of sharper penalties'. There was to be much more to the national 'reformation of manners' across the provinces in the century that followed, as a massive bibliography of Ingram's writings on this theme over the last thirty years shows. But this book marks his deeply impressive and summative achievement.

Moreton-in-Marsh

ANTHONY FLETCHER

\section{Misery to Mirth: Recovery from Illness in Early Modern England. By} Hannah Newton. Oxford University Press. 2018. xiii + 272pp. $£ 60.00$.

With her second monograph, Hannah Newton makes a series of specific historiographical contributions to the field of medical history. The book is focused on completion of the cycle of illness: she sees recovery from it as a liminal space between disease and health. Casting aside more pessimistic treatments of the subject, she insists that complete recovery 'was thought to be possible' in the early modern period. She introduces a number of medical concepts which should be in standard use, like the 'neutral body', analeptics and the healing agent we call 'Nature'. Throughout, Newton argues stridently for the interconnections between spiritual and bodily health. She accepts the dominant Protestantism and the middling and gentry status of many whom she quotes, but she is very aware too of the poor, so wonderfully portrayed as she says by Patricia Crawford. Most memorably, her Oxford English Dictionary is always at hand for her, as she puzzles over definitions that have intrigued her or may surprise her everinquisitive readers.

Newton's account is rooted in intense involvement in the humoral body, as it was consistently lived and hardly questioned from the sixteenth to the eighteenth century. She almost seems to live in it herself, such is her identification with it. A massive and unyielding research effort, told almost entirely from primary manuscript and printed sources, lays the foundations of her argument. One is 
hardly aware of the absence of a bibliography of secondary sources, so immensely thorough is her footnoting. Yet Oxford University Press might have allowed her more pages in a short book for listing all the books and articles which she drew upon. For here is an eager, industrious and deeply perceptive historian, at loose in a field where her confidence is outstanding and her story is wholly convincing.

No book has taken on board with such ferocious conviction, as she does, the infant history of the emotions, which must surely now join the established conceptual apparatus with which we explore the social world of the European past. Most striking of all is Newton's stress on Nature, the body's own healing power after God's. Here she surpasses herself in her creative index making: we have its 'female personification', its 'negligence or weakness', its 'inherent powers and use of the spirits', its roles in 'concoction of bad humours, in expulsion of humours and in strengthening the body after illness'. That may make it sound as if this is a very technical and abstruse monograph, but, such is the clarity of Newton's approach, there are no such worries.

So how, in six neatly conceptualized chapters, does she make the book work? Part I is about 'Medical Understandings' and the first chapter is fundamental. Here, Newton argues that three parties, God, Nature, and the physicians, interacted to defeat disease. Nature was a principal agent of recovery, 'personified as a benevolent female who looked after the body'. Disease was the enemy and the body was a battlefield. Levinus Lemnius, one of Newton's favourite authorities, echoed the view that, choosing a masculine metaphor, he acted 'as a faithful consul in intestine war . . . to cast forth the disease'. Lemnius marvelled at the variety of exits by which humours left the body. Physicians then, in a power dynamic with Nature, assisted the process of expulsion. This revisionism, quite fairly trumpeted as such by Newton, has been 'largely overlooked'.

Convalescence was intimately connected with the 'non-natural things', the dietary and lifestyle factors in recovery. These, Newton maintains, did more than influence the balance of the humours, changing the condition of the 'spirits'. Secondly, in a prognostic function they measured growing health. Convalescence dealt with the neutral body, cast in a liminal space between health and disease: Galen saw it as a melting pot, a 'medium between healthful and unhealthful bodies'. She explores it because it is so important to her in expounding the category of convalescents. This was the stage between the body's 'final purge', before feeling hungry, growing cheerful and 'sitting up to go abroad' occurred.

The rest of the book, driven by a huge mass of wonderful primary material, is about 'personal experiences'. Chapter 3 concerns 'feeling better', for Newton a deeply sensory experience. 'It was through the eyes and ears', she insists, 'that relatives and friends came to share the patient's suffering and eventual relief'. Her focus is on both patients and family and friends. She is fond of the notion of 'fellow feeling' which she believes 'centred on the emotion of love'. She uses the concept immaculately. In chapter 4, she argues that the spiritual experience of recovery was 'shaped by what can be called 'the art of recovery', defined as 'a set of moral duties and devotional practices derived from Scripture'. Here she is consciously revisionist, seeing deliverance from disease interpreted as divine mercy even into the eighteenth century. She draws here, as throughout, on the work of Alex Ryrie, who preceded her in his stress on the 'holy affections', so vital 
in the emotional and spiritual lives of Protestants. Fellow-feeling also illuminates public thanksgiving for healing. For those who watched the sick, Newton shows, 'dichotomous passions held the soul in suspense', as they strove 'away from or towards death or survival'.

In the last chapter, Newton has one overarching argument. The transition to resuming everyday life 'was often found to be physically liberating, socially bonding and mentally stimulating'. Her two basic variables, gender and socioeconomic status, remain firmly in view in this discussion. Newton moves through standing, walking and dressing to going downstairs and outside, where, as Alexandra Walsham has stressed, the outdoor world 'provided manifest evidence' of God's existence. If recovery was a journey from isolation to social life, it was also one from idleness to working life. Not that Newton believes the sick normally ceased work altogether. Her slant here is overwhelmingly positive. Work restored reputation as well as strength. Ralph Josselin, after a fever in 1644, prayed to God so 'I might go on in my calling'. At the heart of recovery were contrasting life situations: 'suffering to ease, misery to mirth, constraint to freedom, guiltiness to innocence'. This was the 'double joy' experienced by people in their bodies and in their souls.

There is a new star in the firmament of English social history. Newton could not be a more appropriate recipient of large-scale funding by the Wellcome Trust. Everything points to the enormous promise that she has shown in her first two books, The Sick Child (2012) and Misery to Mirth. Her next major project, on experience of the senses in the early modern world, will allow her to show how formidable her capacity for historical analysis has become.

Moreton-in-Marsh

ANTHONY FLETCHER

\section{Hospitaller Malta and the Mediterranean Economy in the Sixteenth Century. By Joan Abela. Boydell. 2018. xxviii + 263pp. £75.00.}

Joan Abela's Hospitaller Malta and the Mediterranean Economy in the Sixteenth Century is a remarkable addition to recent historiography on the Mediterranean, rethinking the region as a protagonist of early modern histories. In analysing Malta's society, institutions, and the political and economic transformations endured during the sixteenth century, Abela provides a compelling analysis of the prominence of the island in that sea. Her case study sheds crucial light on the south Mediterranean Sea as a frontier where identities, both religious and political, were constantly negotiated; where a people, torn between old practices and new forces and suspicious of the other nonChristian powers, adopted a pragmatic and hypocritical approach, exploiting all the opportunities that a frontier offered. After the compelling analysis offered by Fusaro's Political Economies of Empire and Trivellato's Familiarity of Strangers, Abela rethinks this sea and its role in the first global commercial expansion, not least as a laboratory of cross-cultural and cosmopolitan encounters.

In focusing on Malta's harbour area, where relations of all sorts were forged, Abela analyses the commercial development of the area during the Knights' rule and the economic activities that took place in Malta between 1530 and 1565; the 
first decades of Hospitaller dominion in a period that has been so far neglected by recent historiography. She draws upon a wealth of documentation, ranging from chancery papers and notarial records, to municipal and administrative documents. She navigates Malta's notarial archives by examining civil law suits, episcopal edicts and inquisition registers. In doing so, she depicts a region featured by dynamism and rife with corsairs, slave traders and ransoms; where diplomatic and economic deals were sealed and called off. By looking at the political and commercial changes at the time, she emphasizes the importance of Malta's geographical position, which allowed control of the east-west passage, and had witnessed for centuries the expansionist ambitions of European powers. By adopting a micro-historical approach, Abela investigates the community under the rule of the Knights of St John; men and women who adapted to new political and economic structures, witnessing influxes of migrants drawn in by the commercial opportunities that the island could offer, and reaping the greatest profit from these new institutional and economic arrangements. By focusing on social and economic changes she sheds light on a broader Mediterranean picture, a history of the people that, from the ground up, allows a deeper understanding of broader macro phenomena.

The book opens with a clear analysis of the institutional changes introduced by the Knights of St John. They were the epitome of Catholicism and military prowess, a force whose policies echoed the Roman tactics of 'divide and rule'. And as the heirs of Roman imperialism, they imposed their power seemingly in virtue of a contract, not presenting themselves as new feudal lords, but contributing to dismantle the old feudal system by ushering in a new mercantile elite. Abela shows that the establishment of a strong political power, coupled with commercial activities of both local and foreign seafarers, motivated and enforced local trade. New incomes were generated and the local rights inevitably usurped. The supposed backwardness of Malta was reversed, and its agriculture commercialized. Finally she explains how the Knights of St John were a power that protected the island and policed the surrounding waters while fuelling commercial expansion. Subsequently, the narrative focuses on commerce and its response to a new society in which social change brought rising prices.

The analysis of commercial activities is enriched with a focus on women who actively contributed to the development of the area by working in trade, both alongside their husbands and independently as sword manufacturers, retailers, or being involved in domestic services. Lastly, Abela looks at this frontier of Christianity where the border was porous. Between east and west the struggle was ancient, just like their constant encounters, clashes and exchanges. Malta, due to its geographical position, was an intermediary between Spanish Sicily, the Levant and the North African coast, a breeding ground for religious encounters split between the Catholic, the Orthodox and the Muslim worlds. Abela's analysis allows a clearer understanding of the relevance of this small island torn between different worlds. She investigates activities largely unexplored in this period of Maltese history and in doing so offers a better understanding of the relations between Europe and 'the rest', whether they were commercial, political or diplomatic. Through this she clarifies the changing role of the Maltese islands within the wider Mediterranean trading community. 
Ultimately, this work shows how Malta built bridges between Muslims and Christians, all of whom had a common goal to make profit. Owing to its ideal location in the central axis of the Mediterranean, the island became an ideal case study to investigate the early modern changes and movements of people, traders and commodities; a place to explore economic and demographic fluctuations, and to analyse the emerging commercial economy with its global exchanges of goods and people. Joan Abela's focus may seem narrow, only a few decades between 1530 and 1565; however, with an engaging writing style, she clearly addresses the significance of this period when the arrival of the Knights Hospitaller profoundly influenced Malta's economy and society. The Knights of St John - like the British much later - respected existing institutions and ushered in a new mercantile bourgeoisie while dismantling the old feudal system. As a naval power, they fuelled economic activities and a monetized economy.

Abela enriches our understanding of the importance of the Mediterranean in global geopolitical phenomena - something that has often been underplayed, but that in actuality played a crucial role, as a site of clashes and encounters where laws, customs and beliefs were constantly renegotiated. This book presents Malta as a protagonist in the Mediterranean; an island whose size is misleading. Although it was at times forced to negotiate its sustenance with the Sicilian viceroys, it was able to weave crucial diplomatic relations with European powers and close commercial partnerships with Ottoman traders and North African corsairs. Finally we see how, despite geographically being a land of frontier, in the economic arena of the sixteenth century Mediterranean, Malta managed to position itself at the core.

University of Warwick

GIADA PIZZONI

Charles I and the People of England. By David Cressy. Oxford University Press. 2015 (2018 paperback). ix + 447pp. £14.99.

David Cressy made his name with a series of monographs on Stuart social history. He only recently turned his pen to civil war politics, with his England on Edge in 2006. This book can be seen as a companion piece to that one, dealing with 1625-40 instead of 1640-2. At the climax of his career, Cressy has come to rest in that haven which many of us have found sooner or later, the Great Rebellion. Was the challenge too insistent for him to ignore? We should be grateful that a fine social historian took this step to bring politics and society together, because this is deeply researched and pondered history, about people's minds and hearts all over England. Here truly are 'the people of England', wanting to be loyal but puzzling, disturbed and driven to question royal motives. Cressy is the most energetic of seventeenth-century historians, visiting over forty archives in England to write this book, besides using the wonderful resources nearer to his home at the Huntingdon Library in California.

'Traditional elite history', Cressy declares, 'sheds little light on five million subjects who by 1640 doubted his abilities and intentions'. In a striking final ten pages he writes of the 'blindness of Charles I'. He could have taken his text from the Puritan cleric who, in a January 1641 letter to Sir Robert Harley, beseeched 
God 'to open the eyes and turn the heart of our king, that he may be thorough for the reformation wished'. We know well in outline how civil war emerged from a long crisis in church and state, one probably largely of Charles I's own making. Cressy takes his lead from a group of historians who have written with much insight about this monarch: Richard Cust, Conrad Russell, Caroline Hibbard and Charles Carlton in particular. The views of others who have joined the debate about the origins of the civil war, like Clive Holmes, Anne Hughes, Christopher Marsh, Alexandra Walsham and John Walter, all receive respectful attention. Kevin Sharpe's account of the Personal Rule is largely laid aside because this book is an ideological story, not one about a king distant from his people, shut away in the aesthetic fastness of his court.

Certainly Charles prized a notion of 'sacred kingship' and expected his people to be dutiful subjects. But, Cressy argues, Charles I was, despite appearances to the contrary, an 'accessible monarch'. Informed by his obsession with order, the court became 'famous for its dignity and splendour'. But Cressy is more interested in the king on the road than the set-piece daily propaganda of Whitehall. We have lacked a proper account of the progresses of Charles I, to set beside those of Elizabeth about which we know so much. Cressy supplies this deficiency, with a mass of splendid detail from a huge range of sources. By his 1642 journey, which ended with raising his standard at Nottingham, the king was 'poorly attended'. But how telling it is that Cressy tells us about his happy reception at Little Gidding, entertained by the Ferrar family with whom he felt at ease. At York in March 1642, only thirty-nine gentlemen accompanied the king on what should have been a magnificent entry to his second city. Cressy's deft summary retelling of the story of 1640 and 1641 makes it evident that by then something had gone terribly wrong in his dealings with his people.

In two long central chapters Cressy comes to the heart of his story. In the first of them, he discusses the nature of Charles's notion of Christian monarchy, noting that most of his bishops were 'anti-Calvinist disciplinarians with high ceremonial and Arminian leanings'. The king's religion is contrasted with 'the people's church'. Charles was interventionist: 'policies designed for harmony and regularity stirred up anxiety and resentment'. A chapter on the royal reissue of the Book of Sports, to be read in all churches, then drives home Cressy's argument about the divisiveness of his religious policies. David Underdown's Revel, Riot and Rebellion (1985) is a central text here but, as always, Cressy has much to add himself that is fresh and pointed. When he explains how sacred kingship was 'eclipsed', it is these crucial chapters which remain most strongly in the mind. Nicholas Tyacke and Kenneth Fincham are his guides here rather than Julian Davies. So, at the end of it all, Cressy's civil war is still about religion more than about anything else.

This book, handling a mass of evidence about popular responses to Caroline policies, perhaps leaves the arguments about why a civil war broke out in 1642 tantalizingly open. In two big books in the 1980s, Conrad Russell traced the fall of the British monarchies and I argued that the civil war was based upon competing myths which captured two sections of the nation. These were our own personal windows on complex historical truth. Cressy's, also a big book, is a third such window. Brilliantly executed and written with enormous verve, his story will surely command enormous respect. It will be read with huge enjoyment by 
many who find Charles I and the outbreak of the civil war perennially fascinating. Cressy's consummate achievement here is in no doubt at all.

ANTHONY FLETCHER

\section{Bristol from Below: Law, Authority and Protest in a Georgian City. By Steve Poole and Nicholas Rogers. Boydell. 2017. xii + 387pp. £70.00.}

The history of urban protest in eighteenth- and nineteenth-century Britain is undergoing a renaissance. Steve Poole and Nicholas Rogers's fine study of Bristol is a valuable and interesting contribution to renewed debates about how urban inhabitants reacted to the major social, economic and political changes of this era. They present a highly detailed picture of urban life and social relations in a once prosperous port, challenged by economic distress in wartime and social and political unrest inspired by the new democratic ideas emanating from the American and French revolutions. Tim Hitchcock and Robert Shoemaker's London Lives (2015) is the obvious reference point for this type of in-depth study of urban life and poverty in this period. Poole and Rogers note that the same range of sources is not as readily available for Bristol as exists for London, but no stone is left unturned in the parish, court and corporation records, weaving a rich tapestry of the interactions between the poor and working people with the local authorities and elites. Though the title suggests this is a history of Bristol 'from below', Poole and Rogers deftly frame their exploration of the motivations and agency of plebeian participants in protest with 'history from above'. As the subtitle suggests, they examine the role of law and local authority in shaping popular politics, and how the structures run by and indeed corrupted by social elites determined the fate of the working poor, though not without resistance.

The central narrative is one of political and socio-economic degeneration. The early chapters examine the range of popular agitation: from weavers' wage disputes in the early eighteenth century to food riots and sailors' strikes culminating in a cross-trade strike in 1792. Yet there was no equivalent radical organization to the London Corresponding Society in the 1790s, and by the 1840 s, Chartism was weak compared with other cities of Bristol's size. What ruined the port's potential for progress was elite corruption: in Poole and Rogers's words, 'empty, extravagant civic rituals, lumpen-voters, the cynicism that comes from political compromise and the rage and recalcitrance of the powerless' (p. 4). Poole and Rogers show convincingly how Bristol bucked the trend of Namierite interpretations of eighteenth-century party politics and elite corruption, arguing that oligarchic power coexisted with vibrant political debate (p. 89). Yet, though Bristol was a freeman borough, with the third largest size of electorate after London and Westminster at the start of the period, the proportion of voters did not keep pace with population growth over the century. Unenfranchised and increasingly economically desperate, the inhabitants sought other means of protest and redress.

Poole and Rogers use Bristol to make an important wider point about histories of the crowd in this period. Poverty and economic hardship were a constant factor that broke the will of inhabitants to organize politically rather than a 
force for motivation. Though they demonstrate that E. P. Thompson's influential 'moral economy' model of crowd behaviour works well with their examination of food riots, the various popular agitations in Bristol went beyond the orderly and ritualized crowd. They convincingly demonstrate in chapters on electoral violence, turnpike riots, naval impressment disturbances, and the panic over a perceived rise in sodomy in the 1730s, that 'crowd disorder often took forms that defy categorisation', and are 'difficult to accommodate within a narrative of protest, resistance and progressive politics' (p. 50). The ways in which inhabitants interacted with the law and its representatives such as justices of the peace did not always follow the neat and tidy model of ritualized prescriptive actions presented in food riots. Here and throughout the book, Poole and Rogers follow the recent thinking of other scholars of historical protest, notably Carl Griffin, in challenging historians' over-eagerness to prove the orderliness of the crowd. Rather, disorder came in many forms, and often relied on the energy and creativity of the crowd rather than more practised rituals and tactics. Chapter 5 is a valuable reassessment of popular Jacobitism, a topic that has not sustained detailed study since Paul Monod's work in the 1990s, while chapter 6 offers a fascinating unpicking of the continued agitation against turnpike construction in the mid-century. Any deference there had been from plebeians to patricians was broken during this agitation, exacerbated by political divisions within the Bristol elites and 'a disposition to panic when large crowds entered the city and only act decisively when troops were behind magisterial backs' (p. 186). The moral economy model of authority negotiation with the crowd was therefore unravelling well before it collapsed in the case of food riots at the turn of the century, as explored in chapter 7.

The final chapters examine the emergence of agitation for parliamentary reform during the American Revolution and the 'mass platform' popular radicalism at the beginning of the nineteenth century, culminating with the Reform Bill riots of October 1831, the largest and most well-known outbreak of violent protest in this era. Poole and Rogers continue their argument about how the potential to organize was met again with subsequent decline. This pattern was perhaps epitomized in the person of Henry 'Orator' Hunt, the radical leader who stood as a candidate in the violent general election of 1807 and spoke to the 'mass platform' demonstration for reform on Brandon Hill in December 1816, but then lost contact with the city radicals in order to focus on his national ambitions. Popular organization was much less well developed than in other industrial and port cities, and Poole and Rogers again lay the blame on the authorities, who suppressed activity as a result of frantic reaction rather than any coherent policy. This was again seen in the Reform Bill riots, which were only quelled after several days by hard-line military intervention. As they conclude, the 1831 riots exemplify the pattern of crowd protest since the 1760s: episodes of unstable coalitions of different groups with varying objectives, exacerbated by the specific party political coalitions and corruption within civic government.

A minor criticism of the book is that the chapter structure jumps around chronologically: the reader is led through to the end of chapter 3 into the electoral politics of the 1820 s, only to be thrust back again to the 1730s in the next chapter on weavers' disputes and the sodomy panic. Nonetheless, Bristol from Below is 
an essential addition to our understanding of eighteenth-century popular politics, protest and local government.

University of Hertfordshire

KATRINA NAVICKAS

\section{Late Modern}

Victorious Century: The United Kingdom, 1800-1906. By David Cannadine. Allen Lane/Penguin. 2017. xxi +602pp. £30.00.

Who will read this book? Forty years ago, I would unquestionably have done so. Like the author, I am the product of a Birmingham grammar school who, in the sixth form, learned to love the study of nineteenth-century Britain. I read all of the overviews - I remember being particularly delighted with L. C. B. Seaman's Victorian England (1973) as much by the way it was written as by what I learned from it - and all of the biographies of the prime ministers (men, Cannadine rightly describes here, 'of exceptional . . . ability and (possessing) impressive erudition and undeniable qualities which would put most politicians today to shame'). Alas, the study of nineteenth-century Britain has virtually disappeared from ALevel courses, and, at undergraduate level, it is in undeniable retreat. The A-Level students of a generation or more ago, seeking to understand why the Corn Laws were repealed or whether Gladstone or Disraeli could claim the greater legislative achievement, are simply no longer there. The sixth formers of today have largely moved on to the twentieth century.

Looking for a new approach, Cannadine has chosen to examine the British nineteenth century not between the traditional starting and end dates of 1815 and 1914, but between the passing of the Act of Union in 1800 and the Liberal landslide of 1906. As he observes, with the disappearance of the Irish parliament in 1800, the political nation was formed; and Balfour is conscripted to remind us that 'the election of 1906 inaugurates a new era'. Cannadine confesses that he will focus primarily on parliamentary and political developments, and that is indeed what he does; but throughout this book there are digressions into technology, art and literature, with some particularly enlightening observations drawn from novels and poetry.

For Cannadine the legacy of Victorian Britain remains powerful. He saw this as a schoolboy in Birmingham, with its palatial council house and magnificent school of art, and he sees it in the long list that he has drawn up of the things the Victorians have bequeathed to us - sewers, railways, football, tennis, telephones, restaurants, redbrick universities, department stores, bacon and eggs, and detective novels (it was from Dorothy Thompson that I learned that the detective novel was the natural form of relaxation for the historian!). 'In some ways', Cannadine concludes, 'the British nineteenth century is not over yet.'

It is an ambitious undertaking to produce a lengthy narrative history like this. It requires considerable reading and the mastery of an enormous number of issues. What soon becomes clear to someone like myself, who has taught and written about Britain's nineteenth century for well over thirty years, is that Cannadine has scrupulously checked his facts. There is hardly a slip to be found - the Chartist leader Feargus O'Connor appears as Fergus O'Connor and 
the number of those shot by soldiers at Newport in 1839 is set too low - but there are no great howlers. This is, however, not a book to be consulted for detail - O'Connor is one of only two Chartists who are actually named - but rather it is about the big picture. And this is where Cannadine excels. He writes so engagingly and the book is easy to read for a couple of hours at a time or to pick up and put down three or four times a day. Throughout there are lovely turns of phrase. Peel sees his Tory colleagues as 'intellectually negligible' and we find Gladstone 'increasingly insisting that God was on his side'. And the appeal of the Great Exhibition is perfectly summed up in a single sentence: 'it was the sheer, miraculous abundance of things that were on display, drawn from all the four corners of the globe, that was so extraordinary and unforgettable'.

If there is a hero stalking these pages, it is Peel, described variously as 'brave and statesmanlike', 'a creative statesman' and the author of the 'brave and innovative' budget of 1842 . Whilst other prime ministers are taken to task for failure of policy - Wellington's views on parliamentary reform, for example, are described as 'preposterous' - Peel is criticized merely for being a poor manager of his party. Some of Cannadine's conclusions are already well established. We are told, for example, that Peel's aim in repealing the Corn Laws was 'nothing less than to ... preserve aristocratic government' - something I learned all those years ago in the sixth form from Norman Gash. Cannadine declares that 'the spirit of the age . . w was improvement and reform'. Indeed it was - except that we should not write out of the story ultra-Tories like Colonel Sibthorp for whom parliament existed not to pass reforms but to protect property and the Protestant faith. And, I will always contend, Charles Kingsley's novel Alton Locke is not sympathetic to Chartism.

So who will read this book? It has been warmly welcomed in the Guardian and a number of other newspapers, and Cannadine will be heartened to learn that copies can be found in the branches of Waterstones in his home city. It is also totting up more readers' reviews on Amazon than most history books customarily secure. And, if you are sufficiently interested in the book to have got this far in this review, you'll probably be considering buying it. If historians mean anything in our lives today, then this book ought to sell well. It is a beautifully written, beautifully illustrated, accurate, clear and reflective survey of Britain's nineteenth century.

Australian National University

STEPHEN ROBERTS

Shaping the Royal Navy: Technology, Authority and Naval Architecture, c.18301906. By Don Leggett. Manchester University Press. 2015. xi +300pp. £80.00.

This important contribution follows the development of professional naval architecture in the era between the first steam warships and the epochal allbig-gun battleship HMS Dreadnought through the prism of the history of technology. In this period warship design moved from a process dominated by artisan construction methods, the structural limitations of wooden hulls, and performance assessments based on simple competitions that could be understood by the responsible politicians, to one where cutting edge industrial technology was introduced into ship design by committees of experts, none of whom 
could hope to master all the scientific issues involved. The individuals who directed this complex process, naval architects, no longer rose from hands-on construction work in the dockyards; they were scientifically educated engineers whose mathematical skills enabled them to predict the performance of large, complex iron and steel structures, steam engines and other technologies. To secure their elite status they set up a professional body, the Royal Institution of Naval Architects, which was intimately linked to specialized education, with a journal that disseminated new methods and ideas.

For 200 years wooden sailing ships had followed a Darwinian evolutionary curve; craft technology constantly improved the species, without radical change. This experience of relative technological stability shaped the assumptions of those who had to respond to industrial technology and rapid technological obsolescence. A series of case studies examines the controversial sailing warship designs of Surveyor of the Navy, Captain Sir William Symonds; the creation of a steam-powered battle fleet in the 1850s; iron-hulled armoured capital ships; the loss of HMS Captain in 1870, which enabled the professional naval architects to assert their authority; the first battleship without sails, HMS Devastation, which proved the value of the new profession; the Royal Sovereign class battleships of 1889, which set the standard for a decade and half; and Admiral Sir John Fisher's transformational Dreadnought. Leggett focuses on contemporary public debates, in which architects, naval officers and shipbuilders contested authority over design in ways that led the wider public to lose faith in the Royal Navy, the most important organ of the nineteenth-century British imperial state. The analysis of these public battles and the underlying status anxiety is well handled, but the role of the Navy Board, which supervised naval design and construction down to 1832, and the Admiralty which took on that role thereafter, in setting design parameters within the wider contexts of naval policy and national strategy, is ignored. This is a curious oversight, given that the Admiralty, not public opinion or professional journals, had the final decision on design. Many contributors to these debates were ignorant, self-serving or mendacious, but readers are left without adequate guidance on the relative importance of the various outputs, or the journals in which they appeared.

Leggett does not engage with the purpose of warships, the critical design parameter, concentrating on how well, or otherwise, they met ideal performance metrics. As any reader of Ships' Covers, the technical design history of nineteenthand twentieth-century British warships held by the National Maritime Museum, will know, warships are built to fulfil criteria set by the end-user, the Navy, not to prove the scientific/technological credentials of their designers. The argument of the book begins to break down when strategic, operational and tactical considerations are factored in. Fisher's Dreadnought was built to win a naval arms race, a consideration that encouraged the adoption of radical new ideas, turbine engines, increased speed, greatly enhanced heavy gun armament and improved fire control, and engaged elite scientists to validate them. Sir William Symonds's broad-beamed warships were built to chase fleeing enemy ships, the biggest tactical/operation problem faced by the Royal Navy during the French Revolutionary and Napoleonic Wars, and to discredit the work of the Navy Board. Earl Grey's Whig Reform Ministry abolished the Board in the same year that it appointed Whig protégé Symonds to an office hitherto held by experienced 
shipbuilders. The same ministry closed the School of Naval Architecture, because the Whigs trusted what they could see, rather than complex mathematics they did not understand. Symonds's ships sailed fast and looked good. HMS Captain sank because it combined a low-freeboard turret-ship, for attacking coastal fortifications, with a full oceanic sailing rig. When the Navy's Chief Constructor, Edward Reed, produced a conservative design to meet this specification, turret pioneer Captain Cowper Coles, who had no naval architectural qualifications, argued that his turrets would only work to advantage in a ship of his design. The ship sank in a gale that did not trouble the rest of the fleet. While Reed knew Captain was unsafe, the politicians, impressed by Coles's promise of cheap naval power, sent it to sea. The 'Manchester' school of economizing radicals made cheap defence a totem, one that William Gladstone took very seriously when he became prime minister in 1868. Furthermore, Manchester leader Richard Cobden had specifically endorsed Coles's work before his death in 1865. Gladstone's government tried to blame Edward Reed for the disaster that followed. The collapse of the French naval challenge in 1870 meant Britain had no significant naval rival for the next two decades, prompting endless disputes about battleship designs that were driven by professional status anxiety, rather than national interest. The leading voice in that debate was that of Edward Reed, who used his professional credentials to condemn every official design. One government held a public inquiry into the design of the Navy's most powerful warship, emphasizing the political consequences of ill-informed public commentary. The spectacle did little to persuade the public that either the Navy or naval architects knew what they were doing. Only in the 1890s did the profession rise above Reed's petty spite. His career was hardly a compelling endorsement of professionalism, or the wisdom of giving authority to those who possessed that asset.

Successful warship designs reflect the input of experienced naval officers and expert naval architects, but politicians provide the necessary funds. They took responsibility for building the ships. The politics of naval policy-making in this era required more attention, an oversight reflected in the underestimation of major published works by other academics. Claims that the work of John Beeler and Jon T. Sumida ignore the human dimension of warship design cannot be sustained. Leggett's book makes a significant contribution to the discussion of naval technology but its restricted focus is not entirely convincing.

King's College London

ANDREW LAMBERT

The British Welfare Revolution, 1906-14. By John Cooper. Bloomsbury. 2017. $\mathrm{vi}+362$ pp. $£ 85.00$.

While Clement Attlee's post-Second World War Labour government is viewed by many people as laying the foundations of the welfare state, John Cooper's book gives credit for the origins of widespread social reforms to earlier administrations, specifically the Liberal governments of 1906-14. While this is a subject that has been covered in some detail by other writers, Cooper here attempts to link all aspects of reform in a single wide-ranging account. Thus the book covers subjects ranging from medical inspections of children, free school meals, provision for 
juvenile offenders, old age pensions, national and unemployment insurance, to housing and town planning, among other topics.

Cooper's contention is that by the early twentieth century the Poor Law, which had been implemented sixty years earlier to cope with the problems of rural distress, had failed under increasing urbanization and industrialization, resulting in cyclical unemployment. Expenditure on relief doubled between $1870 / 1$ and 1905/6. He argues that the need for reform was initially recognized and driven by a counter-elite whose members, inspired by Idealist philosophies and pursuing a sociological approach to the problems of poverty, put forward radical plans for social improvements which the Liberal government largely accepted and implemented. However, motivation was not just altruistic, as the reforms allowed middle-class graduates to expand career opportunities. If schoolchildren were to be inspected, then more doctors were required. If young offenders were to be placed on probation, then probation officers were needed. More specifically, new welfare organizations required new civil servants to oversee their operations.

Cooper particularly emphasizes the importance of sociological studies such as those by Booth and Seebohm Rowntree in influencing reform, along with the Fabian Society, Christian Socialism and the Settlement Movement, which was established, he contends, to quicken the pace of social reform, rather than just to promote it. He also stresses the part played by women in organizing numerous committees and councils which agitated for reform. However, it is sometimes difficult to see how some of these quite small organizations were able to influence government policy at the highest level. Cooper identifies a good deal of personal contact between reformers, such as the Webbs, and politicians at social events and dinners, but fails to convince that this was truly instrumental in causing the level of change which the Liberals brought about. By stressing that the Fabians, for example, were highly influential, Cooper glosses over the fact that the Society members were often at odds with each other about policy. Likewise, as much as civil servants played an important role in the implementation of social reforms, it is more difficult to see how they could have driven change from below during this period.

Cooper divides the reforms into three periods, considering the motivation of the personalities who led the party during each. The first three years, under the leadership of Campbell-Bannerman, who was largely uninterested in reform, was a time when policies were largely restricted to child welfare. Cooper regards these as 'barely noticed', even though they helped to establish the Edwardian period as the 'age of the child' with reforms in a range of areas from child health to new treatments for child offenders. The second phase, from 1908 to 1911, was led by Asquith and Lloyd George, who had greater personal interests in implementing welfare reform, and were also increasingly coming under pressure from trade unions and the labour movement for more radical social change. This was the period which saw the introduction of old age pensions, land reform and National Health insurance, as well as budgetary reforms which provided the means to pay for them. The third phase, which lasted until the outbreak of the Great War, took in a period of domestic unrest, and concentrated on municipal housing and town planning, as well as public health issues ranging from infant welfare to campaigns to combat tuberculosis and V.D. If the war had not intervened, further 
new initiatives in secondary education and the introduction of a minimum wage might have been implemented.

Where Cooper's study proves particularly valuable is in its consideration of the international aspects of reforms, for example, citing how reformers took note of successful campaigns against the sweated trades in Australia and New Zealand and used them as models for their own actions. Developing improvement in communications during the period meant more international conferences were held to discuss aspects of welfare. Ideas about slum clearance and town planning were regularly discussed with German colleagues, and Cooper also discusses the influence of French and German models of secondary education on the thinking of British educational policy. More emphasis is given here to new ideas from within the empire, and also beyond, than has often been the case in considering early twentieth-century reforms, demonstrating that Britain's social innovations were not particularly innovative and far from unique.

This book will no doubt be of great value to those studying social change in the period prior to the Great War, yet while the depth of detail is impressive, the sheer weight of information means the book sometimes becomes unwieldy and repetitive and the thread of the author's argument is sometimes lost in a mass of information. Also, there is little information regarding how the reforms were viewed by those whose lives they affected. Cooper does take issue with the idea that the poor always disliked and resented any government intervention by evidencing how popular old age pensions were right from their introduction, but other examples of how reforms were seen by the general population might have enhanced the discussion and widened the analysis. Nevertheless, this is a work of considerable scholarship, and a welcome addition to the literature on the expansion of the modern bureaucratic state.

University of East Anglia

ALISON JAY

The Russian Revolution 1905-1921. By Mark D. Steinberg. Oxford University Press. 2017. $\mathrm{x}+388 \mathrm{pp} . £ 19.99$.

During the centenary year of the Russian Revolution a slew of works has appeared promising to re-evaluate, re-imagine or provide novel accounts of the events of 1917. These have appeared at such a rate that both scholar and lay reader alike will surely have had difficulty keeping up with the ever-changing literature. Accounts of the revolution provide different assessments whereby basic chronology, key terms and areas under consideration are up for debate. Though the major events have been well attended to by many scholars over the years, some of the debates surrounding the revolution and its legacy remain far from settled. There is contestation over the best periodization to use; the meaning of the revolution today; whether the revolution was broadly a positive or negative event for Russia and, indeed, the entire world; the international significance of the revolution; multiple meanings of the revolution in both centre and periphery regions; what it tells us about both men's and women's experiences of Russian life, and so forth. In such a crowded field what can the scholar offer apart from a refinement of their own approach towards Russian history and some perceptive reassessment of often well-trodden ground? Mark D. Steinberg's contribution is 
to say something novel about the revolution by looking at the multiplicity of meanings of revolutionary change that emerged from around 1905 up until the end of the Civil War period. Given Steinberg's research interests and particularly his recent works on the history of emotion in Russia, the author is well placed to write about events whilst stressing change and subjectivity. The book is split into three parts. The first considers documents from the period and how they illuminate a wide variety of stories. The second covers more conventional terrain, being composed of three chapters covering 1905 until the end of the First World War in Russia, 1917 itself and then the Civil War. The third and most detailed part of the book - the part that, one gets the impression, Steinberg really wanted to write - considers four interlocking but diverse areas: street politics; women and revolution in the villages; Russia as an empire and, finally, utopian dreams of revolution and the changes it could potentially lead to in Russian life. Potentiality is stressed throughout this work - the revolution, 100 years on, remains an unfinished story.

A key motif throughout this work is that of freedom, and particularly 'how people understood, lived, and practiced "freedom" (p. 5). We meet a diverse range of social groups - peasants, workers, soldiers, sailors, students, both men and women - that bring home to the reader the key point that the Russian Revolution was a vast social experience with a multiplicity of possible and often competing interpretations. We meet a wide range of peoples - Jews, Ukrainians, peoples from Central Asia. Drawing on his previous work on working-class consciousness in revolutionary Russia, Steinberg illustrates his work with poems and musings of people from all walks of life who experienced the revolution first hand (pp. 24-5). The conventional readings of high politics are here - the July Days, for instance, are discussed as potentially an 'orchestrated . . . attempt by the Bolshevik party to seize power' (p. 75), but continually Steinberg pushes home the point that revolutionary experiences involved the masses - literally, millions of people including workers and peasants. Steinberg is careful not to romanticize this period, noting that throughout 1917 and after the idea of the disciplined revolutionary proletariat was constantly challenged. Instead, what emerged was the 'complex experiences, needs, ideas, and emotions of lower-class peoples' (p. 159). Popular struggles, hope for change and socialist strategy existed alongside fear, distrust and even hatred of different social orders and religious, national and ethnic groups. Whilst the revolution undeniably offered hope to a great many people, Russia was caught in a brutal epoch of violence that brought chaos, misery and suffering to millions, leaving vast numbers of casualties. Therefore, the book sounds an understandably pessimistic note at times, as it became clear that the potential for popular change was fading away once the state and party controlled the revolution and, increasingly, its meanings (p. 159).

This book is an ideal introduction to the Russian Revolution. As a work of synthesis, it is a masterpiece. Readers will be introduced to key debates in the literature, both older and more recent, and some of the problems that the professional historian of Russia faces when trying to recover voices from the period. Steinberg's lucid writing and careful selection of a wide range of primary sources mean that the book does not lose focus even in the sections dealing with complex subjectivities and deeply personal accounts of the revolutionary experience. Though this book stresses instability and (in my view sensibly) does not offer strong or final conclusions, Steinberg offers a portrait that, on balance, 
is on the side of the revolutionary dreamers: those who were passionately gripped by the idea of change, and in spite of huge risks, tried and often failed to make the leap to a new kind of society.

University of Southampton

GEORGE GILBERT

Russia in Flames: War, Revolution, Civil War, 1914-1921. By Laura Engelstein.

Oxford University Press. 2017. xxvii +823 pp. £25.00.

The centenary of 1917 demands a comprehensive overview of the war, revolution and civil war that raged across the vast territory of the Russian empire between 1914 and 1921. Engelstein answers this call with her epic Russia in Flames, in which she situates the long-standing historiographical notion of Russia's 'continuum of crisis' within its imperial perspective. A drama in six parts, Russia in Flames moves between empire-wide and regional perspectives, while also including personal histories of the revolution for key political figures and military commanders. Engelstein represents 1917 as the high point in the long deterioration of the authority of the imperial regime. The years that followed were characterized by the continuation and escalation of brutal violence, social and economic upheaval, and collective action.

Russia in Flames leaves a lasting impression on the reader in its absolute refusal of simplicity. Engelstein illustrates the period between 1914 and 1921 as one of constant dynamic interactions between leaders and ordinary people, driven by political, social and ethnic concerns, as well as the omnipresent quest for survival. In line with recent scholarship on 1917 in regional perspective, Engelstein reaches to the corners of the Russian empire to illuminate the extraordinary and multifaceted experiences of revolution and civil war. See, for example, the many excellent chapters in Sarah Badcock, Liudmila G. Novikova and Aaron B. Retish (eds), Russia's Home Front in War and Revolution, 1914-22, Book 1: Russia's Revolution in Regional Perspective (2015). By skilfully bringing together recent and older scholarship on the revolutionary period from a variety of regional contexts, Engelstein's overview makes it impossible for future historians to write about 1917 without including perspectives from beyond the metropole. In addition to putting 1917 at the centre of imperial history, Russia in Flames seeks to 'people' the revolution. Throughout the book, Engelstein focuses on how change was pushed from below and how those in authority grappled to control and direct the underbelly of mass violence and social unrest brought about in the face of unprecedented political and economic instability. In light of this, there could have been greater engagement with recent social histories of the late imperial and revolutionary period. This approach would have demonstrated how the history of 1917 can be written simultaneously from 'above' and 'below'.

Part I focuses on the 'festival of mobilisation' (p. 7) that swept across the Russian empire between 1905 and 1907. Engelstein weaves a complex web of interactions between ordinary people, political actors, educated elites and those in authority to illustrate the chaos and possibility of the early years of the twentieth century. The revolutions of 1905-7 are shown to be the result of a growing desire for political action and expression from across the social spectrum and the blatant disregard for legality among the tsar and his ministers. Although key 
political figures pepper the narrative, Engelstein does not disregard the actions, reactions and ambitions of the Russian empire's vast and diverse population. The fittingly named Part II ('The Great War: Imperial Self-Destruction') details how the empire tore itself apart through the stirring up of popular resentment against designated groups, deportations and brutal massacres during the First World War. Engelstein illustrates how the imperial state sanctioned and exploited violence against 'suspect' populations, but also how this violence sometimes reflected a collapse of authority, as military leaders grappled to reassert control over the volatile forces unleashed through widespread social dislocation. Jews, Germans and Armenians were the principal targets of the 'maniacal xenophobia' (p. 69) that permeated society at all levels and influenced the directives of many of the empire's military leaders. The brutal violence perpetrated against these civilian populations reflected the toxic atmosphere of paranoia and suspicion and the authorities' inability to police the legitimate use of force.

The revolutionary year of 1917 is situated right at the centre of the epic in Part III. Elegant descriptions of the movements of female protestors in Petrograd and the centrality of the Tauride Palace in the months that followed offer a vivid spatial history of 1917. Although Engelstein gives an overview of key events and political leaders, ordinary people are the chief actors in the saga. Engelstein notes that revolutionaries did not start the February revolution or have any direct role in the fall of the monarchy, and that 'popular discontent outstripped the capacity of any political leadership to contain or direct it' (p. 159). Far from a foregone conclusion, the Bolsheviks' road to power was riddled with 'twists and turns, plans, revisions and accidents' (p. 177). Individuals and communities in urban and rural settings helped to produce the revolution by committing assaults on emblems of authority and privilege, voting in various elections, and forming committees to alleviate the problems facing their immediate localities.

Parts IV and V sweep across the territory of the Russian empire to explore the impact of 1917 and the civil war in Ukraine, Poland, the Baltic states, Finland, Arkhangel'sk, Transcaucasia, Crimea, Siberia and Central Asia. Engelstein synthesizes the literature for each case study with great care and sensitivity, and aptly illustrates how the developments of 1917 were entangled in the social, political, economic and environmental characteristics of specific regions. The finale of Part VI explores how the Bolsheviks utilized policies of War Communism and ruthless repression as they sought to build a new state apparatus in the aftermath of October 1917. Collective action continued throughout this period, as urban and rural dwellers protested against deteriorating living conditions and resisted the Bolsheviks' suppression of grassroots democracy in favour of top-down government control.

Overall, Engelstein's overview is engagingly written and succeeds in vividly illustrating the complexity of the revolutionary period. Russia in Flames is extremely useful for specialists and non-specialists alike and, with the inclusion of a clear and comprehensive historiographical essay, an important text for all students of modern history.

Durham University

SIOBHAN HEARNE 
1917: War, Peace, and Revolution. By David Stevenson. Oxford University Press. 2017. xxxviii + 480pp. £30.00.

The story of 1917 is largely one of failures: most of the major strategic initiatives undertaken by each side were unsuccessful, as were the peace proposals mooted by the Central Powers and the Pope. David Stevenson's new book provides a masterly analysis of decision-making at the highest levels in all the major belligerents, offering careful and nuanced judgements as to how and why these initiatives failed. While many historians have sought to explain how the war began, we have fewer answers to the question why it proved so hard to end. Having previously offered a convincing and detailed assessment of the war's conclusion in With Our Backs to the Wall: Victory and Defeat in 1918 (2011), Stevenson now sets out to explore how the war was 'constructed' and prolonged through the dramatic global turning point of 1917.

In this readable and detailed transnational study, which draws on archival and published sources in four languages, fascinating contrasts between the belligerent powers emerge. Beyond the complex and much-debated relationship between civilian and military leaders, Stevenson analyses the extent to which effective collective decision-making procedures were developed, as the rapid evolution of the strategic situation placed enormous strain on existing decision-making systems. Stevenson's narrative restores agency (and personality) to the men in charge, highlighting that the continuation of the war was the result of many choices, while acknowledging that over time the range of options grew steadily more constrained by the consequences of prior decisions. The complex German debates over the adoption of unrestricted submarine warfare reveal that while options did in fact exist, there was nonetheless a growing perception in some circles that no real substantive choice remained.

The decision-makers' lot was an unenviable one. Mounting casualty figures kept up a permanent pressure, and everywhere the desire to end the war was strong. But at what price? From late 1916 onwards, national and international discussions about war aims - both in public and behind closed doors - became increasingly important as statesmen sought to establish firm preconditions for possible peace negotiations. Another vital question was how long the war would last: at the start of 1917 the German government considered it imperative to end it within the year, while the British were already planning for the conflict lasting into 1918. On all sides it was thought better to fight a little longer, sacrifice a little more, rather than end the war immediately without any gains; only Lenin embraced peace at any price.

The framework provided by the two alliance blocs was essential. At the November 1916 Chantilly conference the Allies had committed to coordinated collective action in 1917, and these agreements undoubtedly weighed heavily: if the French went ahead with the Nivelle Offensive despite their doubts in part because of their undertaking to the British, so too did the British commit to their Flanders Offensive at least partially because of their obligations to France. Yet Stevenson's meticulous narrative reveals just how far each belligerent made its decisions individually rather than in concert: at times each operated quite disconnected from its allies, and individuals were not above dragging in an ally simply to boost their own position within an internal power struggle. Meanwhile, despite ongoing cooperation, as at Caporetto, 
German and Austro-Hungarian interests began to appear increasingly divergent during the course of 1917 , or so their failed peace initiatives seemed to imply.

The year 1917 saw new powers both great and small join the conflict. While US entry into the war brought immediate relief to the European Allies in terms of credit and material, and the invaluable reassurance of future manpower, it also created a political problem: if the war was not won - or at the very least the Central Powers significantly weakened - before American forces took on a major operational role, the Allies risked seeing their contribution to the eventual victory downplayed and years of sacrifice nullified in the face of a US-led triumph. Inevitably, if this were to occur, it would be the United States and not France or Britain which shaped the peace settlement. Thus while Congress's vote in April 1917 was warmly welcomed in Paris and London, it also gave a new urgency to operations for the year ahead. The February Revolution in Russia was likewise a double-edged sword for France and Britain. A democratic ally was more palatable politically than an autocracy; on the other hand, the Entente partners rightly feared that Russian commitment to the war effort, already in doubt, would further waver under the pressures of the revolution.

Stevenson highlights the general fear of inaction: the Allies' major offensives were all driven by the fear that doing nothing would undermine the nation's position after an eventual allied victory. The risks of inactivity were great - but so too were the dangers of poorly conceived action. His judgement is unequivocal: Russia would have been much better off not launching the Kerensky Offensive, which doomed the Provisional Government, and France would have been significantly better off without Nivelle's flawed offensive, which Stevenson notes, 'might well have lost the Allies the war' (p. 142). He is equally damning on Passchendaele - 'It would have been better, in fact, to do nothing' (p. 202) - and he blames both the generals responsible and the ministers who failed to live up to their promises to monitor the progress of events closely and call a halt should it degenerate into a new Somme. Curiously, Caporetto, the most successful of the year's big land battles, is analysed more from the Italian perspective than the Central Powers'; it would have been useful to learn more about the Austro-Hungarian decision for a battle which arguably came close to giving them victory and yet which ultimately weakened them fatally.

Finally, Stevenson takes on the global turn which in recent years has illuminated the field of First World War studies. Ranging from the Middle East to China, via Brazil, Siam and India, these chapters offer much that may be wholly new to many readers. Three key developments are highlighted, each with far-reaching consequences for the rest of the twentieth century: Chinese intervention, support for Zionism, and the changing relationship between Britain and India. Their importance is undeniable, although they remain substantially separate from the main narrative of the book. This work offers a gripping and chastening analysis of how and why the war was prolonged, and why 'costlier and riskier options' were repeatedly chosen, despite the appalling toll of the war.

John Cabot University

VANDA WILCOX 


\section{Policing Transnational Protest: Liberal Imperialism and the Surveillance of Anticolonialists in Europe, 1905-1945. By Daniel Brückenhaus. Oxford University Press. 2017. xi + 300pp. £56.00.}

Daniel Brückenhaus's study on transnational anti-colonial activism during the first half of the twentieth century constitutes a highly readable analysis and a welcome addition to the ever growing field of transnational history. It is based on an impressive amount of basic research in French, German, British and Indian archives. The book has an ambitious dual focus: firstly, it offers an analysis of how British, French and German surveillance agencies and police forces established frameworks for international cooperation through new networks of surveillance and cross-border structures for information exchange to find new ways to monitor and suppress anti-colonial activists in Europe. Secondly, it forms a study of these anti-colonialists, their activism and transnational lives in the European metropoles. Brückenhaus argues convincingly why these two perspectives must be treated as inherently intertwined as the increasing surveillance on the national level pushed anti-colonialists repeatedly to relocate within Europe. As Brückenhaus demonstrates, the anti-colonial activists were not only moving 'vertically' from the colonies to the European centres but an important 'horizontal' movement and transnational networking took place between London, Paris and Berlin that radically influenced national and international governmental surveillance practices.

The book is divided into six main chapters, which follow a strict chronological structure that focuses explicitly on 'inner European transnational connections', rather than activism outside Europe. International surveillance practices were first expanded within the framework of the Entente Cordiale, between 1905 and 1914, when British and French police forces initiated new forms of cooperation to monitor Indian anti-colonialists active in Britain, France and Germany. While anti-colonial activists were grimly suppressed in the colonies and mandates according to the principles of autocratic colonial rule, anti-colonial activism taking place in the European metropoles was safeguarded by the liberal principles of government. However, even in Europe anti-colonial activities could be criminalized if they were deemed 'seditious'.

Brückenhaus demonstrates throughout the book the importance of properly integrating Germany into the history of anti-colonialism and surveillance. Imperial Germany constituted initially a common enemy that pushed the BritishFrench surveillance and policing cooperation to new heights. Their major fear was that Germany would secretly support anti-colonial activists working against the British and French empires, or even form a sort of anti-colonial pact. As Brückenhaus reveals, in some cases these fears were also realized when for example Indian activists cooperated with German officials during the First World War. It forms one of several important examples to be found in Brückenhaus's fascinating source material, which illustrates how the anti-colonialists were able to utilize the political divisions within Europe to find supporters for their anticolonial agenda. Although the alliance between Germans and anti-colonialists ended in 1917, Brückenhaus distinguishes a much longer trajectory of antiGerman thinking in British and French officials' security reports. After Imperial Germany's collapse in 1918, inventive interpretations of the concept of European colonialism were introduced. Nationalists, communists and far-right circles in 
Germany entertained the idea that in the new 'Versailles system' Germany now belonged to the oppressed peoples of the world. Like the colonies, it needed to be liberated from the oppressive imperialist rule of the British and French, and Germany was even described as a 'European India' in the making. From a French and British perspective, the major fear was thereafter a 'Germano-Bolshevik' alliance aimed at bringing down, in cooperation with the anti-colonialists, the British and French empires.

It was perhaps only the emergence of a new powerful international threat that enabled the further formal surveillance cooperation between France, Britain and the pro-western part of the German authorities in the 1920s. As Brückenhaus discusses in chapter 5, the fight against anti-colonialists converged in a significant way with anti-communist agendas during the League Against Imperialism (LAI) years, 1926-33. The LAI constituted a significant case in the history of twentiethcentury anti-colonialism when the radical left and many communist and noncommunist anti-colonialists strove to find unity in a first global front against the European empires. Significantly, as the LAI conceptualized its anti-imperialist agenda as a way to unite all oppressed peoples in transnational cooperation, it pushed British and French surveillance cooperation into a stronger pro-colonial common front. It also illuminates the importance of Berlin and Hamburg as transnational contact zones for international communists and anti-colonial activists. However, by the early 1930s, the available space for anti-colonial and left-wing activities in Germany was rapidly diminishing. Finally, under Nazi rule after 1933 the left-wing anti-colonial organizations were banned and the key activists were imprisoned or forced to flee the country. Nazi Germany was nevertheless forced to balance its racial policies against maintaining good foreign relations and trade connections. Interestingly, Brückenhaus demonstrates how for example the British were prepared to refrain from opposing the Nazis' domestic racial and oppressive politics if they, through surveillance cooperation with the Nazis, could help maintain and protect the British empire. Brückenhaus provides the reader with a stimulating analysis of anti-colonial activity in the Nazi era, but surprisingly the effects of the Molotov-Ribbentrop non-aggression pact between Germany and the Soviet Union are omitted in the analysis. The pact had far-reaching consequences beyond the German and Soviet contexts as it forced the international communist movement to redirect its attention from anti-fascism to a renewed support of national liberation movements in the British and French colonies. Before the pact, anti-fascism and the Popular Front policy had pushed the anti-colonial agenda into the background. When the GermanSoviet pact fell apart in summer 1941, the anti-fascist agenda resurfaced again, now ordering for example that Indian communists postpone their demands for independence and accept (at least temporarily) an alliance with the British and French empires in the struggle against the Axis powers. Disillusionment with communist-led anti-colonialism resulted in many breaking with the Soviet Union during the 1930s. However, as Brückenhaus shows in his pivotal analysis, many difficult moral and tactical choices had to be made in rapidly changing, complex political circumstances between the anti-colonial, anti-fascist, pro-colonial or even pro-Nazi positions before and during the Second World War.

Brückenhaus analyses correctly the efforts of the anti-colonialists as a form of transnational activism that crossed borders and continents on a civil society level. Although temporary strategic alliances with various state powers were made, 
the activists themselves sustained in many cases their own agency and steered their activities towards the liberation of the colonial peoples and decolonization. However, on a critical note, although Brückenhaus shows that surveillance networks were turning international, they were still intergovernmental or 'international' rather than 'transnational', which is a term that should be reserved to describe networks and movements beyond governmental structures. For the benefit of a coherent historical analysis they cannot be used interchangeably. The introduction of descriptors such as 'transnational surveillance' (pp. 7 and p. 81), 'transnational governmental surveillance' (p. 212) or 'transnational colonial surveillance' (p. 221) are therefore not very helpful for the analytical framework of the book. Although Brückenhaus rightly concludes that the conflict between those fighting against colonial rule and the police authorities took the form of 'a feedback cycle in which both sides caused each other to become more transnational in the scope of their networks' (p. 4), it remains analytically correct only for the transnational activists - not the governments policing and surveilling them. Although the book shows the importance of increasing connections and cooperation especially between French and British surveillance agencies, it would have been interesting to find a more systematic comparison of policing and surveillance practices in the authors' conclusions. On the other hand, the book manages to open up the often monolithic image of 'the authorities' and shows the importance of looking at the inner developments and conflicts within the surveillance and police agencies.

In conclusion, despite some analytical shortcomings, Brückenhaus's study makes a significant contribution to the research field and shows the importance of researching transnational protest movements through surveillance sources. This unique body of material provides us with remarkable insights not only into the internal operations of the activists, but also into the surveillance strategies utilized on an international and global level that maintained and preserved the European empires throughout the first half of the twentieth century.

Åbo Akademi University, Turku, Finland

KASPER BRASKÉN

\section{Leningrad 1941-42: Morality in a City under Siege. By Sergey Yarov. Translated by Arch Tait. Polity. 2017. xiii + 409pp. £35.00.}

The winter of 1941-2, the first winter of the Soviet Union's war with Germany, was what Leningraders called the Time of Death. Leningrad's food reserves were already low in early September 1941, when a German and Finnish blockade closed around the city. By October, Leningrad doctors were seeing the first cases of what they called dystrophy - starvation. Between 20 November and 25 December, the daily bread ration for office workers, dependants and children fell to a low of 125 grams. In January 1942, temperatures reached 40 degrees below zero (the point at which centigrade and Fahrenheit converge). Leningraders suffered famine and bitter cold in a city without heat, electricity, running water or public transportation. They lacked the capacity to count, let alone bury, all the dead. Corpses piled up in the streets and courtyards. Perhaps 
as many as 1 million Leningraders died, primarily of starvation, in that first brutal winter of the blockade.

Sergey Yarov's book provides a harrowing and moving account of this season of death. He draws on hundreds of letters and diaries written during the blockade as well as retrospective memoirs to examine the breakdown, reformulation and maintenance of 'moral standards' and 'civilization' in the city under siege. He sets up his study as a contrast and a corrective to the stories of 'gaudy heroes' produced by the Soviet 'propaganda machine' (p. 160). This is not to say that Yarov denies that Leningraders were heroes. On the contrary, he argues that his close and critical reading of siege documents allows us to see 'real people, irate, resentful, but still imbued with a sense of compassion' (p. 160). In Leningraders' descriptions of starving people offering help in the direst circumstances he locates the authentic heroes of the blockade, people who tried to maintain moral standards amid death and degradation.

Central to Yarov's project is an assessment of 'siege ethics', the shifting 'moral code' (p. 31) by which Leningraders tried to live - or by which they judged others - during the siege. As he presents them, Leningraders' 'concepts of morality' scarcely drew on Soviet discourses and norms. Unlike historian Alexis Peri, whose The War Within (2017) analyses some of the same diaries, Yarov is not interested in Soviet subjectivity. Rather, he emphasizes the universal 'moral commandments' ( $p .31$ ) - honesty, fairness, charity, compassion - that emerge from his reading of siege documents. On the rare occasions when Yarov characterizes Leningraders as Soviet people, he does so mainly in order to stress that specifically Soviet codes of conduct, for example according privileges to Party bosses, did more to undermine than support what he considers true morality. He explains the Soviet clichés that sometimes crop up in the diaries of more ordinary Leningraders as a consequence of the fact that the 'norms of communist morality ... were to a considerable extent based on traditional ethics' (p. 280).

Outside the highest party circles, Yarov finds complexity and paradox in Leningraders' efforts to 'remain human in a time of inhumanity' (p. xiii). Organizing his discussion of the documents around shared themes - appealing for help, expressing gratitude, helping or withholding help from family members, co-workers and strangers - Yarov emphasizes both that each story was highly individual and situation specific and that individual morality could not be maintained in isolation from the community. For example, he emphasizes that any number of circumstances might push Leningraders to refuse help to someone in need. Yarov understands the self-justifications that Leningraders offered in such cases as an acknowledgement of shared norms and as a means of ensuring that 'ethical rules' not be 'cast aside, even when they are increasingly being broken' (p. 85). On the other side, asking for the help of those who were also starving required 'ruthlessness', but such pleas, Yarov argues, also 'strengthened the commonly accepted moral rules' (p. 108). For Yarov, a central tragedy of the blockade was that attempting to maintain moral standards often required cruelty and callousness.

A short review cannot do justice to the sensitivity and thoroughness with which Yarov uses the 'testimony of eyewitnesses' to lead readers 'into the very depths of the hell that was Leningrad during the siege' (p. 324). Still, he finds 
some light amid the darkness and despair. Even as he rejects what he describes as a long-standing tendency in accounts of the siege to 'gloss over descriptions of human weakness and helplessness' ( $p$. xi), he credits the stories of compassion and charity that he finds alongside depictions of anguish and horror. Leningrad, he concludes, 'saved itself though redeeming actions great and small' (p. 324).

Yarov takes as his foil the 'canonical' Soviet view of the siege that offered Leningraders 'unambiguous confirmation of their heroism' (p. xii). For scholars of the blockade, questioning the canonical history of the siege has become fairly standard practice. What makes Yarov's book an important contribution to the scholarship of the blockade, and indeed of the Soviet-German war more generally, is his innovative approach to understanding the blockade as a communal trauma. Focusing on 'morality in a city under siege' allows him to approach war as destroying not only individuals but also their social worlds. Yarov's exploration of how individuals under unimaginable conditions tried (and often failed) to maintain the moral norms that held their communities together will be of interest to historians of war and trauma well beyond the Soviet context. This fluent and readable translation by Arch Tait should ensure that the book gets the wide audience it deserves.

West Chester University

LISA KIRSCHENBAUM

\section{The Consumer on the Home Front: Second World War Civilian Consumption in Comparative Perspective. Edited by Hartmut Berghoff, Jan Logemann and Felix Römer. Oxford University Press. 2017. ix + 371pp. £80.00.}

The end of the Second World War is frequently memorialized as the great break of the twentieth century. Iconic images of Hiroshima flattened by the nuclear bomb, or the streets of Warsaw or Berlin reduced to heaps of rubble, symbolize the so-called Stunde Null or Zero Hour. Such scenes of total destruction represented an absolute break with the past and the start of a distinctly modern form of new post-war prosperity. The post-war decades saw the rise of the United States as the undisputed leader of global consumption, and the rise of the defeated Axis powers of (West) Germany and Japan as international symbols of affluence and advanced material production. Within Europe, the end of the war meant not only the division of the continent along new Cold War lines, but also, and on both sides of the Iron Curtain, the end of the recurrent food shortages that had plagued the continent for the first half of the century. This excellent anthology asks us to look more carefully at such narratives, suggesting not only that continuity as much as rupture link wartime to the postwar period, but also that commonalities across states and political structures fascist Germany, imperial Japan, democratic Canada - are as striking as are differences.

Taking as its starting point the home front as the site of wartime private consumption, this collection examines case studies from the major belligerents who were operating independently (i.e. not under occupation). Thus, case studies explore Great Britain, Japan, Germany, Canada, and the United States. This is an unusual grouping, but quite effective in establishing thought-provoking examples of unanticipated commonalities and connections. The distribution is 
uneven, with Germany (four chapters) and the USSR (three) predominant, but the inclusion of both Canada and Japan add productive and significant material. Interestingly, although the United States is referenced regularly as the dominant force in post-war global consumer culture, only one chapter - Jan Logemann's study of the post-war rise of American expertise in consumer studies - directly discusses it.

Food is a major theme throughout the book (though the discussion of tobacco in Nazi Germany as a 'food-like' consumer object is unnecessarily awkward), and the collection definitively shows that food was a key concern for governments of all stripes during the war, in more prosperous countries as well as those plagued with severe hunger crises. Wendy Goldman's study of the USSR focuses on workplace canteens, a central place of food distribution and consumption throughout the wartime and post-war world, yet one rarely discussed in studies of consumer culture. Great Britain offers a remarkable story of post-war consumer economies, as the only non-communist country to initiate a strict food rationing programme after the war's end, and, under the Labour Party, to construct a short-lived narrative of peacetime abundance that was compatible with restricted private consumption. Canada pursued a policy of 'cautiousness' marked by the unique adoption of a universal price freeze for the duration of the war, successfully preparing the ground for the country's gradual post-war prosperity; in contrast, devastating food shortages proved more significant for Japan's surrender than the dropping of the atomic bombs.

The collection is noteworthy for exploring not only necessary objects of daily consumption like food, but also for addressing high fashion, the sort of 'frivolous' consumption object assumed insignificant or simply non-existent in times of crisis and conflict. The anthology shows us that quite the opposite is true. In fact, focusing on fashion challenges many assumed truths; we learn, for example, that Nazi designers operated in a surprisingly permissive space, where they openly constructed the ideal Nazi fashion as international, modern, urbane and non-productive. Equally unexpected, in the USSR at the peak of the war effort, Stalin allotted a surprising amount of support to high fashion, going so far as to open the Moscow-based House of Fashion Design in 1944. Several studies of wartime advertising culture were similarly productive. British advertisers successfully linked constructions of a future democracy with private consumption, while Nazi Germany prohibited the use of Nazi symbols in advertising campaigns, asserting a desire to keep Nazi ideology 'free' from the taint of the marketplace, and Japanese magazines promoted 'frivolities' like lipstick even at a time of widespread and quite desperate shortages as a marker of patriotism.

Like all good anthologies, this one provokes many questions and suggests themes that could not be taken up adequately in the actual collection. For example, the theme of transnational exchange is central to the collection, but is dealt with unevenly. Jan Logemann analyses the impacts of refugees on American social scientific thinking about consumption, and several chapters mention the way in which military movement across space ensured the transfer of new ideas, products and consumer fantasies (Spiekermann, Zhuravlev). However, Sheldon Garon's chapter on the food situation in wartime Japan is the only piece really to grapple with the significance of the transnational as a link between war and consumption. More importantly, gender is 
under-explored, which is a disappointment as theorizing with and through gender has been central to scholarly research on consumer culture. While chapters on fashion, cooking and advertising spoke about women as target audiences, and even as designers and leaders in their respective fields, and in all cases wartime consumption was clearly understood as women's responsibility, none of the authors uses gender to theorize the relationship between war and consumption.

Nonetheless, all of the chapters are well-written and speak to one another, while providing fascinating case studies in their own right. This collection conclusively confirms that the war should not be conceptualized as a break or even a step backward in the development of a modern consumer culture. War impacted consumption in countless ways, both constructive and destructive. Equally as important, the collection argues for a global and transnational approach towards understanding the history of consumption. Consumption depends upon neither peace nor affluence, but rather plays a crucial role in modern warfare. It is a vital part of everyday life across states and political systems, shaping public and private spheres, and reflecting individual and collective hopes as well as fears.

Loyola University Chicago

ALICE WEINREB

\section{Women in the Holocaust: A Feminist History. By Zoë Waxman. Oxford University Press. 2017. 181 pp. $£ 30.00$.}

To some, a monograph seeking to examine women's experience with a historical event using a feminist lens seems like it should have been written fifty years ago. However, as Zoë Waxman correctly notes in her introduction to Women in the Holocaust: A Feminist History, Holocaust Studies has lagged behind in its use of historical methodologies. Not only has it been extremely late in using gender as a lens, it has even been hostile to examining the particular experiences of women and the Holocaust. I recall as an undergraduate in the late 1990s trying unsuccessfully to find an adviser to supervise a senior thesis examining women's experiences in concentration camps. This was at a women's college where I had been steeped in scholarship about women but no one felt qualified to oversee a thesis which examined women's suffering during the Holocaust. At the time I raged, but in retrospect it was not just women's experiences that were getting little attention in the field of Holocaust Studies. Most historians in the field of Holocaust Studies at that time were focused on questions related to the perpetrators of the Holocaust rather than victim experience. Other than examinations of resistance and some older works on the Judenrat, there was not much historical scholarship being done on victims. It was not until I was already in graduate school in 1998 that Dalia Ofer and Lenore J. Weitzman published their book Women and the Holocaust, which gathered articles from scholars around the world to discuss the particular experiences of women. The book caused a backlash, prompting debates on whether the experiences of women needed to be differentiated from those of men or if utilizing a gender lens was a political act which disrespected the field. 
Topics examining the specific experiences of women continue to receive pushback in the field and the number of books dealing with women's experiences is sparse. For example, despite the criminalization and prosecution of rape as a genocidal act and the subsequent opening of dialogue on women's vulnerabilities to sexual abuse during genocide, it took a long time for works examining sexual abuse during the Holocaust to be accepted and published. Works on women's reproductive experience including pregnancy, abortion and related issues have appeared but there is room for more. Even the diaries and contemporary writings of adult women have yet to appear widely in print whereas men's diaries appear in print in abundance.

Waxman published her feminist history because she noted that men's experiences during the Holocaust are still treated as normative (p. 6). This is further evidenced by the paucity of Holocaust works which examine masculinity. Waxman's book is an indictment of the field of Holocaust Studies, which continues to lag behind.

As part of her corrective, Waxman draws widely on primary and secondary source material to examine women's experiences in ghettos, in hiding and in concentration camps. Her contribution in this work is not only in highlighting the specific experiences of women but also in contributing to the still slowly emerging field of Holocaust victim experience. In each of these broad chapters, Waxman seeks to explore issues specific to women's experiences. She utilizes testimonies to highlight issues that have been engaged with by various scholars but which will probably be expanded upon by future scholars, including sex in the ghetto and the ranges of consent, the rapidly emerging subfield examining intimacy during the Holocaust, the role of women in resistance and how their bodies unlike men's could serve as camouflage, the gendered expectations for women in food preparation and household management in the ghettos, the vulnerability of women in hiding, and other issues.

Waxman teases out and highlights issues which are particular to women but which have not been deeply examined. The book itself is slim and does not delve very deeply into these topics either. It leaves instead a trail for future scholars to follow and a path for them to forge deeper into. It reminds the reader that things like sexual abuse or being vulnerable are not just part of being a woman at any time: they take on specific significance in the context of genocide.

What Waxman's book most significantly accomplishes is to present an unapologetic call to correct a long-overdue problem with Holocaust Studies. Waxman calls on scholars to differentiate between and compare male and female experiences; she calls for a restoration of and amplification of female voices, and a pushback against the male Holocaust experience as normative. Waxman provides a reminder that women's testimony and experiences have a unique contribution to make to the field of Holocaust Studies which has largely been dismissed or ignored by scholars. This work is appropriate for classroom use as well as an important corrective for scholars to heed.

University of Tennessee

HELENE SINNREICH 
Postwar Germany and The Holocaust. By Caroline Sharples. Bloomsbury. 2016. viii +238 pp. $\$ 29.95$.

The study of Germany's Vergangenheitsbewältigung (overcoming of the past) has been at the core of the new field of Memory Studies. Sharples provides an excellent overview of the historiographical debates, key events and key moments in Holocaust memorialization in Germany since 1945. Sharples synthesizes the debates and issues surrounding the commemoration of the Holocaust in Germany while keeping in the foreground the contested nature of terms like 'memorial' and 'memory'. In highlighting the political imperatives of memory and juxtaposing them with the emotion and requirements of all victims of the Holocaust and Nazi brutality to remember and mourn, the book demonstrates the complexities and nuances that must be understood in order to engage with and understand Germany's changing relationship with its Nazi past.

Sharples explores the differing ways in which the four Germanys (Occupied, East, West and United) have dealt with the years between 1933 and 1945. Rather than trying to tell a chronological narrative of the changes and continuities, the book successfully breaks down the attempts to come to terms with the past into themes and examines the conflicts found between German narratives of suffering and the victims of Nazi racial and political persecution. The themes covered relate to post-war justice, memorialization, Holocaust education; the role of German churches in offering explanations of the Nazi regime and genocide, and media representations of the Holocaust and Nazi crimes.

Each section deals with the core issues that are central when considering coming to terms with the past: the way in which guilt is a blocking emotion and prevents meaningful reflection on an individual's human agency. Sharples shows how the assertion of terms like 'victimhood' or 'victim' often results in the treatment of memory of the past as if it was a zero-sum game in which only one party is entitled to such classifications. The book also highlights the ineffectiveness or insufficiency of language to represent past trauma and suffering, particularly because the universality of terms like 'victim' means different things in contexts, and in relation to distinctive crimes and events. The contested nature of these terms is highlighted in the frequent political battles over memory in Germany since the end of the Second World War and is at the core of this book. It may have been interesting to explore how notions of victimhood or suffering had their roots in the defeat of the First World War and whether these narratives helped shaped the post-1945 German discourses of defeat and reconstruction.

Of particular merit are chapters 6 and 7, which deal with the distinctive attempts to depict the Holocaust in film and television and to memorialize the Holocaust in the differing political entities of post-war Germany. In these chapters, Sharples offers not just a history of memorialization and attempts to capture the Holocaust and the Nazi regime in visual media but also explores some of the theoretical and moral concerns that are connected to such endeavours. These chapters are also the most comprehensive in dealing with the different political and geographical constructions of Germany post-1945. The one small critique to offer is that in some places the book tends to focus on West Germany and unified Germany with East German representations of the Holocaust being overshadowed, particularly in chapter 5 on the responses of churches in Germany to Nazi persecution. 
The work is an excellent overview of the key issues connected to Holocaust consciousness in Germany. It is also prophetic; the last lines of the book explain that memory work in Germany remains ongoing. As the book was published in 2016, the results of the 2017 federal election were unknown to the author. It is clear that, with the populist right-wing party Alternative für Deutschland (AfD) gaining 12.6 per cent of the vote and 94 seats in the Bundestag, new questions about the success of Holocaust representations and memorialization will need to be asked, particularly because of the party's strength in the former GDR Länder. A re-evaluation of the past of a divided Germany and its attempts at Vergangenheitsbewältigung will need further scrutiny. Nevertheless, Sharples's book should be on every undergraduate reading list on modules dealing with Modern Germany, the Holocaust and Collective Memory. It is certainly a text to recommend to any student studying this period or anyone interested in how Germany has dealt with its Nazi past.

University of East Anglia

MARK HOBBS

\section{'Tomorrow Belongs to Us': The British Far Right since 1967. Edited by Nigel Copsey and Matthew Worley. Routledge. 2017. 276pp. \$44.95.}

This anthology examines fascist and far right groups in Britain during the past fifty years with attention given to issues beyond electoral history and quantitative political science studies. These insightful chapters employ historical and cultural studies approaches to explore subjects, including Holocaust denial and conspiracy, political economy, transnationalism, youth culture, beliefs about homosexuality, and gender and women. Nigel Copsey and Matthew Worley's introduction explains that the collection of essays is built around the 1967 establishment of the National Front, which marked 'an important milestone when a new coalition' developed and 'a revitalised far right emerged' (p. 7). The title refers to a popular far-right song by Skrewdriver, which ironically has its origins in a song from Cabaret, a 1972 anti-Nazi musical drama, written by two American Jews.

The first half of the book centres on far right discourses and ideology, symbiotic relationships and transnationalism. Mark Hobbs examines the far right's use of Holocaust denial to 'rehabilitate Nazism' and how denial gave farright activists a way 'to make sense of the world', namely a Jewish conspiracy that prevented them from achieving electoral power (p. 10). He argues that the two issues were 'mutually exclusive' as denial alienated the public and could not be easily discarded as it was a plank of far right ideology. Turning to a specific political organization, Daniel Jones and Paul Jackson analyse the National Socialist Group that was established in 1968 and ended in 1969 by reviewing letters, membership records and party publications. Finding the group had little impact as a social and paramilitary movement, the authors consider that it was part of wider changes in British neo-Nazi culture and played a 'role in sustaining the most extreme forms of far-right activity in Britain' (p. 44).

John Richardson studies the 'nationalist' economic policy of the National Front during the $1970 \mathrm{~s}$ and $1980 \mathrm{~s}$ and argues that the two different 
political economies failed to 'transcend' the 'capitalist political economy' and 'recalibrated' capitalism to aid the nation. As for transnationalism, Evan Smith describes the National Front of Australia as a case study of British fascists trying to export their ideology and Australians seeking to develop a local version of the party. He argues that the failure to establish a National Front foreign branch 'falls into a wider history of a British-styled fascism being exported to Australia and elsewhere within the British Commonwealth, yet failing to thrive outside of its original domestic context' (p. 71). Alex Carter explores the 'cumulative extremism' between fascists and anti-fascists by analysing factors, such as 'collection action frames' and internal cohesion, that led to tactical escalations between opponents from 1967 to 1979.

The second half of the book focuses on culture, gender, sexuality and a review of literature about the far right. Exploring cultural spaces, Matthew Worley and Nigel Copsey look at efforts by the National Front and British Movement to 'claim' youth culture, particularly punk music, as a 'conduit' for fascist ideas from 1977 to 1987. They argue that 'The far right's engagement with youth culture from 1977 comprised three overlapping processes to contest, colonise and construct' which 'took a variety of forms' (p. 126). Continuing with fascist music, Ana Raposo and Roger Sabin explore the role of visual identity in fascist music by analysing record sleeves, publications, badges, and other images between 1982 until 1987. The authors describe how 'Changing visual obsessions between 1984 and 1987 tell a story of new influences (Nordic myth, heavy metal) and of new priorities (European unity)' (p. 145). Next, George J. Severs discusses homophobia and homohysteria in the British National Party during the 1980s and 1990s, positioning party anti-gay discourse in 'traditional' fascist conspiracy theories and in the context of the HIV/AIDS crisis of the 1980s. Hannah Bows highlights literature and gaps in knowledge about women's involvement in a variety of British far right groups, offering ideas for future scholarly research. She explains: 'while men remain numerically dominant in support and activism in the far right, these groups are no longer closed to women and the traditional ideologies of the far right are shifting' (p. 181).

Turning to transnationalism, Graham Macklin looks at the impact and context of Greece's Golden Dawn on the British far right, arguing that Golden Dawn's ideological militancy and social welfare programmes influenced the British National Party. He explains that Nick Griffin, then leader of the British National Party, 'appears to have calculated that brazenly supporting' Golden Dawn 'could serve as a backstop to his waning influence and relevancy, both nationally and internationally' as well as help 'his tarnished credibility amongst the hard-line activists' (p. 200). Moving to domestic issues, C. M. Quinn explores the English Defence League as a social movement with patriotic love, pride and loyalty being a motivating and transforming factor for individuals, according to interviews with a few dozen activists. She argues: 'Patriotism together with emotional responses to grievances has shifted respondents from a passive affective patriotism to an active patriotism whereby respondents started to take action' (p. 220). Lastly, Craig Fowlie provides a bibliographical survey of primary and secondary sources about the British far right since 1967 that describes and critiques literature about parties, social movements and subcultures, including the British National Party, English Defence League, National Front and United Kingdom Independence Party. He writes that overall 'the scholarship has done an 
excellent job of researching, describing and analysing this multifarious activism' and future research in areas such as the relationship between the far right and violence, as well as discourse analysis, is needed (p. 248).

'Tomorrow Belongs to Us' is an excellent contribution to studies on the British far right, demonstrating cultural and transnational elements of extremism. The authors provide several new insights into far-right subculture and ideology that highlight issues such as the roles of gender, sexuality, youth, music and transnationalism. As with any anthology there are several gaps due to the limited space for each chapter, notably homophobia or Islamophobia in the British National Party after 1999 or detailed analysis of women's roles in the British National Party or National Front. Moreover, the chapters are not always connected chronologically or thematically as the authors discuss a variety of groups and individuals that span a wide spectrum of ideology. In addition, the scholarship could have situated the far right within the wider post-war context, namely Thatcherism and the Conservative governments from 1979 to 1997. This is a highly recommended collection of chapters, and scholars and students will also find Craig Fowlie's extensive bibliography useful for research.

Independent Scholar

RYAN SHAFFER

\section{The Americas}

Outside In: The Transnational Circuitry of US History. Edited by Andrew Preston and Doug Rossinow. Oxford University Press. 2017. viii + 284pp. £19.99.

Outside In brings together a series of thought-provoking essays which showcase the breadth and diversity of the field of US transnational and international history. Andrew Preston, an expert in the history of US foreign relations, and Doug Rossinow, an authority on US social and cultural history, gathered a group of scholars. Specifically, four themes are studied: Pacific and transatlantic crossings, religious actors, black internationalism and the internationalism of the far right.

The first essay, by Jay Sexton, elucidates how a core concept of nineteenthcentury US diplomacy, the Monroe Doctrine of 1823, was not a 'proclamation of national exceptionalism' (p. 29). Rather the declaration that warned the European powers not to recolonize Latin America emulated British policies and the manifestos of the Holy Allies. Conversely, with the rise of US power the doctrine became more famous and other countries declared Monroe Doctrines of their own. Daniel Sargent analyses how the increased interdependence of the US economy with the rest of the world in the 1970s made managing the global economy more difficult. Policymakers in the 1970 s were therefore not ignorant or indifferent, Sargent argues, but rather struggled with the destabilizing implications of globalization. Leslie Butler's contribution explores how AngloAmerican interactions led to a reinterpretation of John Stuart Mill's ideas and unintentionally narrowed the way in which US liberals defined women's voting rights. Marilyn Lake's 'White Men's Wages' concludes that Australian labour reformers developed the proposal for the living wage in response to the threat of cheap Chinese labour. Those ideas were exported to the US, which was obsessed 
with Chinese immigration. Lake focuses on H. B. Higgens, the President of the Australian Commonwealth and Arbitration Court who influenced American reforms, particularly during his trip to the United States in June 1914.

Missionaries were transnational actors par excellence and therefore constitute the second theme of Outside In. Ian Tyrell concludes that 'missionary movement created networks that brought a greater American entanglement with the wider world' (p. 111). Melani McAlister provides a concrete example of this in her essay when she argues that 'violence against Christian missionaries in Congo became a symbolic site' for understanding how race, faith and politics were being reimagined in the postcolonial context of the 1960s (p. 143). The case of Paul Carlson, a missionary who was gunned down in Stanleyville in 1964, was a key moment in which 'American-ness' was formed at home and abroad (p. 144). Darren Dochuk's work on Great Canadian Oil Sands Limited lays bare the strong bonds that existed between evangelical Protestantism and the petroleum sector. Alberta Premier Ernest Manning, in particular, sought to advance the 'millennial dreams' that were stirred by oil. Manning 'filtered eschatology and economics' into politics as he was building networks to protect the Canadian oil interests (p. 163).

Minkah Makalani addresses the third theme of the publication, namely black internationalism. She studies its rise through organized communism in the 1920s, which is seen as a critical moment when black radicals brought race 'fully into the discussion of imperialism' (p. 189). She therefore concludes that US political history should be seen as part of the wider story of the African diaspora. Elizabeth Tandy tells the story of Luther Hodges, who through incessant networking and transatlantic travel tried to boost the industrial development of North Carolina.

The last set of essays tackles the issue of right-wing transnational movements. Rossinow demonstrates that internationalism did not only exist on the Left, but also had a right-wing version with rightist elements in the United States mingling with groups abroad. He shows how French and British ideas about counterinsurgency filtered through to US thinking. Moshkin Temkin writes about the ways in which US activists were forced to alter their activism in the face of a French state that worried about the import of foreign political problems in the course of the 1970s. It is particularly striking that extreme right-wing groups also came under surveillance.

Understanding the bigger picture that emerges from these eleven snapshots is challenging. For one, some conceptual clarity would have strengthened this collection. It is argued that both 'international history and transnational history focus on topics that both cross and transcend national borders' (p. 3). The key difference is considered to be that international history is 'top-down', while transnational history is more 'bottom-up'. International history is presented here as an updated version of diplomatic history as practised by Leopold von Ranke. However the field of international history today includes multi-centric history and is more interested in describing what the international system looked like to different actors, while the most innovative accounts have focused on the creation of international norms and the idea of 'the international' itself.

Moreover, the editors could have taken a clearer position in the academic debate on transnational, international, comparative and global history. The book states that it is 'far from the first book' (p. 4) and does not offer 
'an entirely new approach' (p. 6). These essays engage only implicitly with the new insights that have emerged in recent years. Where does this group of scholars stand, for instance, on Jeremy Adelman's essay, 'What is global history now?' (Aeon, 2 March 2017), which points out that historians who want to break out of the mould of the state often privilege the optimistic cosmopolitan narrative and ignore the adverse effects of transnationalism? Rossinow's contribution on the Dirty War Network hints at the darker elements of transnationalism, but does not explicitly address its implications for the field. Similarly, Makalani's essay on black internationalism points out that if the nation proves inadequate, transnationalism and internationalism are not entirely satisfying alternatives' (p. 184). Moreover, more explicit attention paid to how decolonization problematized but also reconfirmed the state as the primary entity in international relations would have given the essays a sharper edge. Within much of the new history of decolonization the state is brought back into the analysis, albeit in more flexible ways (see, for example, Jeffrey James Byrne, Mecca of Revolution: Algeria, Decolonization, and the Third World Order (2016), p. 9). Temkin's essay comes to a similar conclusion when the 'ultimate limits of internationalism' as well as the 'enduring power of the state' are stressed in a study of US political travellers to France (p. 262).

Methodologically, the introduction embraces presentism because it allows for the 'recovery of historical worlds that have been unjustly forgotten' (p. 2). Nonetheless, the risk of such an approach emerges one page later when the authors write that the "mid-twentieth century period of high nationalism, which once shaped our view of all the history that came before, now begins to look anomalous' (p. 2). It is a strange observation for a book published in the year Donald Trump was elected president and the United Kingdom decided to leave the European Union.

In short, this book enables readers to rethink the methodological implications of transnational history. It is extremely difficult to find a useful text that reveals to students the multiplicity of how 'the lived experience of North Americans took shape within, and was constituted by, a circulatory system that was intrinsically transnational' (p. 7). This edited collection can therefore serve as an excellent example to show how far the field of transnational history has come and provide inspiration for new work.

Utrecht University

FRANK GERITS

\footnotetext{
A Nation Without Borders: The United States and its World in an Age of Civil Wars, 1830-1910. By Steven Hahn. Penguin Books. 2016. x + 596pp. £25.00.

This ambitious and wide-ranging volume is an important addition to the literature on the nineteenth-century United States and is an accessible read for enthusiasts, students and academics alike. It forms part of Penguin's fivevolume chronological series on American history and so, in many ways, might be seen as a traditional history book, adopting the chronological, high political approach. But, as Steven Hahn says, this is a 'familiar story told in an unfamiliar way' (p. x).
} 
Hahn takes empire as the central model of governance in this period and sees the imperial ambitions of the United States as an important driver of change. But this is an economic as well as a political history as Hahn traces the processes through which capitalism became established in the United States. As referenced in the title, the narrative of the book is also defined by a reconsideration of borders and borderland spaces, within the United States itself and between the United States and the wider world. This is an exciting and innovative approach and one that foregrounds new stories about the American past and challenges long-held views of American exceptionalism and the tendency of many survey volumes to focus primarily on the eastern and western seaboards.

Many of the stories told in this volume are indeed familiar ones. For example, chapter 1 covers the struggles over the identity of Texas, the Mexican war, Andrew Jackson's Indian policy and hostility to a national bank. But each of these topics is framed in such a way as to enable the reader to challenge their conception of what the United States is at any given moment, and what constitutes its porous and mutable boundaries. In chapter 2, slavery, and resistance to it, are similarly approached from a transnational perspective, with actors such as Denmark Vesey appreciated more widely for their efforts in the early nineteenth century to grow the space allowed to people of African descent.

Chapter 3 tells a story of economic development by once again placing domestic evolution in the light of international changes. As in previous sections, the historical moments discussed are not new: for example, the significance of the changes to transport infrastructure and the blurred boundaries between slavery and freedom in this period. A brief discussion of the role of religious revivals, the women's movement and the temperance crusade also follow in this chapter, and Hahn convincingly argues that female reformers constructed a new view of domesticity and separate spheres. The following chapters, essentially looking to the fracture of the nation in the Civil War over the issue of slavery, present key moments in political history (the 1857 Dred Scott case, for example) while also narrating a holistic story of the impact this turmoil had on native and black Americans. The coverage of the years immediately following the war focuses briefly on Reconstruction and then on the capitalist boom-and-bust cycle. For readers new to this material, the detail provided ably illustrates the complexities of this period.

The naming of chapter 10 as 'Imperial Aims' might lead the reader to think that Hawaii, the Philippines or Cuba were its focus, but rather Hahn presents in imperialist terms the struggles for dominance of the US South and elimination of Native American resistance. This argument is broadly convincing. The last two chapters focus on the struggles for a voice led by both radical and conservative reformers at the turn of the twentieth century, and the new imperial adventures which Hahn rightly argues were influenced by experiences in the south and west of the continental United States.

Although some readers may find the lack of footnotes and explicit engagement in the text with previous scholarship an irritation, these omissions are compensated by a lengthy bibliographical essay, which is clearly laid out and fulfils the functions of being both synthetic and interpretative, extending over more than fifty pages. 
This volume contains much to recommend it, especially to the novice scholar unfamiliar with this period. It builds on the latest scholarly work, for example about borderlands, the global economic ramifications of slavery, and the foregrounding of resistance, among other topics, and presents a coherent telling of the story of the emergence of the United States as an imperial nation, full of fascinating detail and surprising anecdotes. Those more familiar with the history of the nineteenth-century United States may wonder how much of this is genuinely innovative, but this volume still deserves to take its place as an important contributor to the sum of knowledge about this complex period.

Loughborough University

CATHERINE ARMSTRONG

\section{The Transatlantic Kindergarten: Education and Women's Movements in Germany and the United States. By Ann Taylor Allen. Oxford University Press. 2017. 304pp. $£ 56.00$.}

Ann Taylor Allen examines the kindergarten's origins and development from the 1840 s to the First World War by taking a transnational and comparative approach. Banned at one point for allegedly promoting socialism and atheism, the kindergartens served more than just children and gave women 'opportunities for professional and intellectual development, personal independence, and a broadened area of social activity and influence' (p. 2). As Allen argues, this effort was not confined within a nation-state, and pushed political, cultural, linguistic and religious borders. She carefully historicizes the ideas, warning readers that current categories do not necessarily conform to thought in the past. Allen not only examines transnational cooperation and collaboration, but shows how by 1900 national competition stopped the international movement.

Allen opens the book by discussing the kindergarten's origins in the early nineteenth century, connecting its foundations to broader social issues and philosophy. Analysing the pedagogies of Johann Heinrich Pestalozzi and Friedrich Fröbel, she highlights how women educating children was a truly revolutionary movement shaped by demands for women's autonomy, helping family and society, and overcame religious differences. This led to pedagogical institutions with advice given by professionals while 'the kindergarten movement devalued mothers whose practices were based on tradition rather than training' (p. 32). Moving to the revolutionary era of 1848 until the 1870s, Allen explains that the kindergarten 'flourished' in the revolution's environment of social change, freedom and reform, but following the 1848 revolution, kindergartens were associated with radicalism and were 'tainted', resulting in some German states banning them. Subsequently, immigrants and exiled revolutionaries made their way to the United States where they used German pedagogical methods and the atmosphere was more 'receptive' to kindergartens, leading to the establishment of the first public-school kindergarten in 1873 and spreading throughout the United States. As Allen argues: 'In the United States, the kindergarten did not throw off its "German" identity to become "American" but provided a transcultural space for the blending of diverse people and intellectual currents' (p. 57). 
Next, Allen explains how dramatic city growth spawned concerns that were transnational, prompting communication across borders and an international movement of women's solidarity. She writes: 'Women reformers focused on issues - child care, early education, maternal welfare - that had previously been consigned to a private sphere of family life, of concern to male heads of household but outside the purview of society or the state' (p. 85). At the same time, new pedagogies were developed, and the purpose of education was adapted to the new environment and influenced by international dialogue, which impacted all levels of education. Notably, universities began offering classes for training and kindergartens shifted from Fröbel's methods to more practical issues as well as health and exercise.

Allen then describes how the institutionalization and integration of kindergartens into public schools happened very differently in Germany and the United States owing to national differences. Partial German funding for kindergartens was aimed to help poor and neglected children in response to 'urban poverty' and 'juvenile delinquency', which limited kindergartens' development, but in the United States 'teaching at lower levels was already defined as female, and teachers' receptive view of the kindergarten influenced superintendents and governmental authorities in its favor' (p. 136). As for the kindergartners, the teachers in the kindergartens, during the twentieth century they widened their goals, and found new opportunities from which they had previously been excluded. Allen explains that in Germany women, even in male-controlled government employment, still identified care work as female, but 'American professional women, by contrast, often considered this ideology sentimental and old-fashioned and adopted a more gender-neutral definition of professional competence' (p. 159).

Turning to the slow decline of transatlantic cooperation, Allen explores shifts in attitudes about cultural differences and the international kindergarten movement's 'bitter' end during the First World War. At the start of the twentieth century, 'the German-American relationship was now almost reversed: originally, Americans had come to Germany as students, but now their success in integrating kindergartens into public-school systems - a goal that Germans seldom realized - had greatly raised their status among their German colleagues' (p. 169). The relationship's phases consisted of friendship, alienation and finally hostility with the war, marked by cultural stereotypes and beliefs about national allegiance superseding transnational relations. Allen concludes the book by briefly tracing kindergartens from the First World War to the present day, demonstrating change and continuity through the Second World War, Cold War and German unification by noting national differences, positive gains and continuing struggles for teachers of young children. As she argues, 'transatlantic alliances, whether among individuals or organizations, provided many essential forms of support: advice, ideas, material assistance, sometimes even refuge from political persecution' (p. 193).

The Transatlantic Kindergarten is an excellent study that brings together many different transnational, intellectual, educational, social and political themes by explaining the interconnectedness of issues such as feminism, societal reform, immigration and academic research. Allen shows how the kindergarten began as more than just an educational project, but it was a feminist and transnational effort that broke new ground and challenged fundamentals of American and 
German societies through international exchanges. The book also provides insight into changes in higher education, but could have discussed what impact these changes had more broadly on primary school education as well as children's transition from kindergartens into primary schools in the different countries. With meticulous archival research, Allen's methodology provides scholars with a useful way to consider transnational topics by interweaving multiple aspects of social, political and cultural developments. Moreover, she nicely demonstrates that comparative history of education can highlight how events and ideas thought to be universal are shaped by national contexts.

Independent Scholar

RYAN SHAFFER

How the Post Office Created America. By Winifred Gallagher. Penguin Books. 2017. 326pp. £23.99/\$18.00.

Imagine inert data, lifeless information, suddenly conveyed from one corner of society to another. The ability to move a letter, a newspaper, or a book and put it into the hands of another at great distance, cheaply and in a sedulously consistent and timely manner, placed the United States Postal Service at the forefront of all American democratic institutions. As Winifred Gallagher persuasively argues, it was their chief building block. Certainly, the post served as a vehicle for knowledge. As Congressman A. F. Lever of South Carolina (1901-19) once put it, the post was 'a great university, ... the schoolhouse of American farmers, ... and is without a doubt one of the most potent educational factors of the time' (p. 210).

First begun in the British colonial period, postal communications were initially meant to dispel the worries of distance. After 1650, when provincial governors were tasked with building the King's Highway from Boston to Charleston, connection between territories was the driver for communications. One leg of this pathway, the Boston Post Road - a route between New York City and Boston - was vital in bringing news, in addition to facilitating commerce. More locally, William Penn instituted a Philadelphia-based mail service. Eventually, connections over land and sea were devised, though at considerable cost. As such, profit became the motivation for innovation in postal efficiency, mode of travel and speed. During America's natal period after the 1780s, it became quickly apparent that the systematization of the post was as necessary as government control. Congressional authorization would be required to budget for payroll and conveyance, and it also regulated the price for both letters and parcels. Consequently, the landscape changed. As demand for home delivery grew, correct and public naming of streets and the enumeration of houses began. Some communities even elected to install sidewalks to facilitate the steps of mail carriers.

Gallagher argues that the creativity and thrift of its postmasters let the post grow with abandon, but inventions such as the telegraph and telephone threatened to halt it. The First World War provided an important respite, particularly when the government seized control of the railroads. The post then enjoyed a stable and steady increase in volume and Postmaster Albert Burleson finally negotiated a new fee structure whereby the railroads would be paid on the 
basis of the space mail required instead of its weight. Under his watch, the price of postage for periodicals increased markedly - the first major jump since the 1790s.

Gallagher's history is filled with stories of the antics of Post Masters General, but they share the stage with no less colourful figures. Women comprise many of the pioneers in postal history. Indeed, its historiography begins with the journal of Sarah Kemble Knight, who chronicled a trip she took in 1704 between Boston and New York City. Her observations of fellow travellers included the Crown's post riders, whose fidelity to the job demanded they ride some 25 miles each day. Years later, some of the first 'Dead Letter' clerks were women. By 1865, the post's Dead Letter Office had thirty-eight women employed there, in contrast to only seven male colleagues. Post-Civil War America also witnessed an increase in the number of female postmasters. In Gallagher's telling, we hear of people like 'Stagecoach' Mary Fields, a six-foot-tall former slave who delivered mail in the Montana wilderness. A cigar-chomping sharpshooter, she had a soft spot for children. When she died in 1914, her obituary was front page news.

Perhaps the three greatest advances in postal shipping came through the creation of moving sorting systems on board trains. This time-saver was used most effectively on short runs, but the use of trains over long distances supplanted the more plodding pony riders, who could only convey as much mail as their steeds could carry. Additionally, aviation spread its wings in the service of speedy delivery. 'Air mail' pilots, often at great risk, tried to out-manoeuvre one another for the fastest routes, fastest flights, and most creative drop points. Lastly, 'rural free delivery' (RFD) allowed those in the country's hinterlands to receive an accommodation that went beyond the reception of a letter. It meant connection to a wider world, no matter how remote one might be. Gallagher points out that these and other advances had the duel effects of moving mail with greater agility, but it also 'burnished the public image of the United States and its post' (p. 226).

We live in the age of email and Amazon, with messages and parcels sent cheaply as never before. Is our post obsolete or, as Gallagher suggests, merely at a new precipice for renewal? This entertaining read is also fodder for this and other large questions about American institutions.

Redemptorist Archives, Philadelphia, Pennsylvania

PATRICK J. HAYES

The Marshall Plan: Dawn of the Cold War. By Benn Steil. Oxford University Press. 2018. xii + 606pp. £25.00.

Among informed citizens interested in International Relations after the Second World War, questioning the importance of the Marshall Plan is presumed to be about as smart as telling one's friends about the bridge you just bought. Not knowing enough about the Marshall Plan is obviously not an excuse, considering the massive amount of literature on the subject. As demonstrated within the pages of The Marshall Plan by Benn Steil, it is challenging to underestimate the importance of this far-reaching event in any analysis of the Cold War. The reasons for this stem from the commonly held view that the Marshall Plan was a paradigmatic shift in world affairs during the twentieth century. In all cases, the Marshall Plan mattered significantly. As such, historians mostly argue about the degree to which it did so and over the consequences of the economic recovery 
that it created. Clearly, the plan included the development of NATO to protect the economic investment among countries accepting aid. In this regard, the Marshall Plan, and especially NATO, led to ongoing division between east and west, the European Common Market, and later, to the European Union. One could add 'and so on' if such a phrase did not trivialize so many important events that followed.

Indeed, it is difficult to account for the tremendous role of the Marshall Plan after the Second World War. The world would, of course, have been far different without it. What if the Soviet Union had accepted Marshall Plan aid to revive a devastated Russia after the Second World War? What would the plan have looked like had it been accepted by the Soviet Union? What would Great Britain look like had it not as constructively modulated the European Economic Recovery Plan in ways that helped it during such economically perilous times? The Marshall Plan provides numerous counterfactuals, outweighed only by the details of the plan, and the geostrategic matters it spurred. For these reasons, the Marshall Plan deservedly remains a considerable subject for historians to evaluate and re-evaluate. Historians, of course, thrive on demonstrating that there is always something more to say.

Benn Steil's work is a positive recent addition to literature on the Marshall Plan and it somehow seems new in many respects. This may be due to Steil's training and experience as an economist since he tilts towards that field in his writing. He successfully manages to create a highly readable book that balances economic-heavy analysis with rich accounts of personalities involved in Marshall aid planning, and, helpfully, this balance is maintained by an organizational framework that moves at a brisk pace. Steil, with an MPhil and DPhil in economics from Nuffield College, Oxford, along with extensive realworld experience as an economist on the Council of Foreign Relations, is a well-respected authority in his field. The comprehensive approach to his subject is also balanced by extensive commentary upon Soviet perspectives through archival work in Russia. Also, Steil's emphases on connections between the Marshall Plan and NATO, required essentially to protect the investment made in Europe, are useful for younger readers to keep in mind. On this point, Steil's analysis of arguments made against NATO, especially those advocated by George Kennan, ties the past to the present. As an example, Steil's comments on Kennan's prescience regarding NATO help contextualize the history of current debates over NATO expansion and its relevance to east-west relations:

In 1997 (Kennan) had written an op-ed in The New York Times arguing that 'expanding NATO would be the most fateful error of American policy in the entire post-war era.' Kennan predicted that it would 'inflame nationalistic, anti-Western and militaristic tendencies in Russian opinion,' 'have an adverse effect on the development of Russian democracy,' 'restore the atmosphere of cold war to East-West relations,' and 'impel Russian foreign policy in directions decidedly not to our liking.' (p. 400)

Steil is at his best when tying together the past's relevance to the present and he does the majority of this in the book's final chapters, 'Success?' and 'Echoes'. One of his most astute points regarding Marshall Plan aid hits home hard. In the case of Afghanistan, Steil writes, 'Aid can be designed to bypass governments, 
and to go directly to the population, but disintermediation does nothing to address the problem that effective government is necessary for development something Marshall's State Department took as a given' (p. 375). In light of present aid distribution, and the ongoing withdrawal from Afghanistan, where its government continues to totter on disintegration in the Taliban's favour, the facts are sobering. The 'combined nominal total of $\$ 171$ billion' (to Iraq and Afghanistan) - as a figure that is 'about $\$ 40$ billion more than the present value of all Marshall aid' - is as outrageous as it is accurate (p. 375). It is common knowledge that so much of this aid was also wasted, at least according to the Special Inspector General for Afghanistan Reconstruction (SIGAR, reporting available at https://www.sigar.mil/allreports/). After completing Steil's book, particularly after considering the important points made in the concluding chapters, readers may wish Steil had tied the past and present together at greater length because there is much to learn from the Marshall Plan for contemporary aid efforts. As it is, however, Steil's book is large, yet it is difficult to imagine how it could have been shorter.

It would be an oxymoron to call Steil's big book too narrow, especially considering the magnitude and importance of the Marshall Plan in Europe and as a critical event in world history. It is understandable that Steil chose to keep his eye focused on Europe only, but the financial aid provided to countries shaped their foreign policies in ways that were of great consequence beyond Europe. US aid to France, as one of the most important examples, enabled the Fourth Republic to facilitate its return to its colonies in Indochina after the Second World War and provided the finances to fight its war against the Viet-Minh. France, in fact, almost spent more on its war to retain its colony in South Vietnam, and its protectorates in Tonkin and Annam (north and central Vietnam, respectively), than it received from the United States during the entirety of Marshall Plan aid to France. Aid data demonstrate that France diverted most of the American-supplied economic aid between 1948 and 1954 to support its operations in Indochina because it knew that American leaders sought to prevent potential communist subversion in France, perhaps more than they were concerned about communist subversion in Indochina. According to Irwin Wall, 'Marshall Plan aid proper to France from 1948 to 1951 was \$2.75 billion, while the Indochina war for that entire period cost only marginally less: an estimated \$2.5 billion or 900 billion francs' (Irwin Wall, 'The Marshall Plan and French politics', in Martin A. Schain (ed.), The Marshall Plan Fifty Years Later (2001), pp. 167, 177).

Why were such massive financial outlays still insufficient to overcome, after 1949, the Chinese-supported insurgency in Indochina? Concerning aid for French forces in Indochina between 1946 and 1954, Eisenhower later affirmed that the United States had no choice but to provide such massive financial support. 'The decision to give this aid was almost compulsory. The United States had no real alternative unless we were to abandon Southeast Asia.' Nor would the French have an alternative for supporting self-determination in Southeast Asia due to the 'serious effects in other portions of the French Empire, including Algeria' (Dwight D. Eisenhower, Mandate for Change (1963), pp. 373, 336). The financial assistance to France, and its diversion for retaining control of its empire is notable, but the overall point is that Marshall Plan aid had significant consequences because of the options it provided 
countries such as France in their foreign policy. This is a matter that is not assessed at any length in Steil's work, unfortunately, and Indochina is not even mentioned.

No one could argue with Steil's point that the Marshall Plan was important. Historians, however, contest the degree to which it forced European integration. According to Irwin Wall, 'Historians have seemed to reach a consensus against the idea that the United States was the primary impulse behind the achievement of European Union' (Wall, 'The Marshall Plan and French Politics', in Martin A. Schain (ed.), The Marshall Plan Fifty Years Later (2001), p. 172). Steil, however, side-steps historiographical precedents and opts, instead, to offer a chronological history of the plan's development. While Steil writes with authority and clarity, and the book is meticulously supported with rich primary and secondary sources, he makes no clear argument that differentiates his work from that written by Charles L. Mee, Jr., Michael J. Hogan, or from essays edited by Martin Schain (see Charles L. Mee, Jr. The Marshall Plan (1984); Michael J. Hogan, The Marshall Plan: America, Britain, and the Reconstruction of Europe, 1947-1952 (1987); Martin Schain (ed.), The Marshall Plan: Fifty Years After (2001)). Among informed individuals seeking to learn more about the Marshall Plan, this is not necessarily problematic. For historians, trained and concerned with historiography, however, lack of a clear academic argument should raise concerns. What makes Steil's work on the Marshall Plan different, better or more accurate than previous books on the subject? Did he find some unknown document that potentially changes our understanding of the Marshall Plan? This is not made clear. The absence of an introduction, in which an argument and historiographical notes could fill this void, is a strange omission. As it is, only a foreword and prologue exist, and the prologue serves as the book's first chapter. It is a stretch to consider Steil's work as comprehensive, therefore, despite its capacious spine, without explanation why it should stand out among other histories of the Marshall Plan.

Steil's approach to the Marshall Plan emphasizes the economic history of the programme. In an important respect, the financial components of the plan and the economic realities facing Europe, of course, were all that ultimately mattered in the first year of the plan - due to food shortages - even though they were inextricably linked to political considerations. Politics and economics, in Steil's work, are correctly presented as two sides of the same coin and he deftly manoeuvres between the two subjects with skill. He addresses, for instance, micro- and macro-economics, and especially the matter of currency in Germany, but does so without losing the bigger picture of how European recovery was the real point. Historians' arguments, in contrast, ultimately seem to centre on whether European integration mattered the most. If this is so, Steil's book is best seen as a history where short-term demands mattered most, not unlike historical accounts of the First New Deal in the United States. The problem with the Marshall Plan, as with the New Deal, is that recovery and integration, or recovery and long-term social security nets in the United States, are difficult to parse. Regarding Steil's economic emphasis, there are certainly soporific passages for individuals not interested in economic details, but his attention to such fine points, validated by his expertise as an economist, strengthens his narrative. 
No book can accomplish everything, particularly considering the magnitude of the Marshall Plan. However, the lack of acknowledgement Steil gives to think tanks, specifically the Council on Foreign Relations and the Brookings Institution, is a considerable omission. Both organizations are mentioned once (p. 199) and only in passing. Senator Arthur H. Vandenberg, the chairman of the United State Foreign Relations Committee, requested that Brookings conduct a study on how such a recovery plan could be organized. The result was a twentypage report, released on 22 January 1948, that provided key recommendations which were put into action when the 80th US Congress enacted the 'Foreign Assistance Act of 1948' on 3 April 1948. (See Ron Nessen and Fred Dews, 'Brookings Roles in the Marshall Plan', 24 August 2016, <https://www. brookings.edu/blog/brookings-now/2016/08/24/brookings-role-marshall-plan/>.) Leo Paslovsky, who led the report and was head of the international studies programme at Brookings, is not even mentioned. Surely, Paslovsky contributed to the Marshall Plan's formulation, at least to a degree? Considering Steil's significant contributions to the Council on Foreign Relations, this seems like a missed opportunity. Indeed, demonstrating the utility of think tanks in the past would only strengthen their case for relevance today. As an example, integrating the importance of think tanks in post-war planning of Europe leading to the Marshall Plan, particularly considering the militant democracy advocated by Hans Speier at the RAND Corporation around this period, is a worthy matter that others have taken up (see Daniel Bessner, Democracy in Exile: Hans Speier and the Rise of the Defense Intellectual (2018)).

These concerns aside, Steil, with the assistance of numerous research associates, translators and interns credited in the acknowledgements, has produced a valuable book. It may not serve as the definitive account of the Marshall Plan, but it certainly is authoritative and is worth the investment of time readers may decide to allocate to it. Considering current controversies surrounding Brexit, NATO in eastern Europe, aid programming by the EU, the United States' role in the world, and so many other problems, it is refreshing to read Steil's account of bipartisan effort in the United States and of agreement within Europe and between allies across the Atlantic. It may be pointless to look back as if those were some good old days of political achievement, of course. Yet, the Marshall Plan, for all its deficiencies, did model intelligence, compromise, foresight and cooperation among political leaders in the west. In this, above all, it demonstrates how current readers deserve far more from politicians, particularly in the United States.

The State University of New York at Albany

NATHANIEL L. MOIR

Cold War Anthropology: The CIA, the Pentagon, and the Growth of Dual Use Anthropology. By David H. Price. Duke University Press. 2016. xxxi + 452pp. $£ 20.99$.

David H. Price's impressive work is the third part of his trilogy that examines the reciprocal relationship between anthropology and America's intelligence agencies. The first part of Price's scholarship focuses on how anthropology in the United States had been affected by the Federal Bureau of Investigation's (FBI) 
surveillance of the 1950s, whilst the second looked at how anthropologists had been used by the United States during the Second World War. This work looks at how anthropology had gained considerable support by the Central Intelligence Agency (CIA) during the Cold War, and how anthropology had impacted upon the United States' quest for global dominance after 1945.

Price paints a very large picture and does so effectively. His study revolves around the 'dual use' of anthropology. Price relates how academic and theoretical work within physical and social sciences has led to commercial and military developments. Obvious examples of dual use are radar, jet propulsion and the nuclear bomb. Other less apparent examples include international aid programmes that may be part of an effort to support foreign governments that support US policy. While physical sciences were quick to recognize dual use, Price's work deals with anthropology's reluctant acceptance of the dual use and political nature of its research. In particular, Price argues that it is not often acknowledged that many anthropological studies of the Cold War period were utilized by the US government in their efforts to fight counterinsurgency.

The work is an in-depth, well-researched study. Price highlights the financial support and assistance that anthropology received from the United States government, from the CIA in particular, using numerous examples of the Cold War's impact on anthropological research. What is surprising, for present-day scholars, is the number of anthropologists who failed to see past their own uses for their research. Academics of the modern era are asked to assess how their work will make an impact outside their own discipline; but, either through ignorance or through naivety, anthropologists initially failed to understand how their work during the Cold War might benefit others, particularly the state. Price's work identifies how the relationship between anthropology and the US government moved away from the aligned collaboration that was prevalent during the Second World War. Anthropologists' optimism in the benevolent nature of US foreign policy dissipated with US Cold War neocolonialism and revelations of the CIA's covert and illegal activities. Price argues that this caused anthropologists' support for US foreign policy to end and caused a considerable number of anthropologists to radicalize, and to support revolutionary movements opposing the United States.

The book is split into two distinct sections. The first part considers the wider subject of anthropology and the federal government agencies, while the second half looks at specific relationships as part of the interactions between American anthropologists and the US state. Price draws on extensive documentary evidence throughout the work, starting with the CIA's creation of the University Associates Program in 1951. The programme was a covert liaison between the agency and university professors at fifty US campuses. It was driven by the agency's concerns surrounding US security following the post-war break-up of colonial empires, expressed in a 1948 confidential agency report. The prospect of expanding the United States' sphere of influence through foreign aid caused the agency to seek help from academics with the knowledge that they needed. Price states that during the 1950s, the American Anthropological Association worked secretly and, at times, unwittingly with the agency by providing lists of members and their areas of specialism. 
The second half examines the various foundations, fronts and individuals that were funded by the CIA, as well as some of the various projects to which anthropologists contributed. Chapter 8 focuses on MK Ultra, the CIA's mindcontrol programme. Price reveals how between 1955 and 1965 the CIA, using the Society for the Investigation of Human Ecology and the Human Ecology Fund as fronts, funded social science and medical researchers. The results of this research would be used for CIA projects such as the Kubark Counterintelligence Interrogation manual, the guide that the CIA would use for interrogation for the rest of the twentieth century. The anthropologists who unknowingly benefited from the CIA funding were unwitting participants in the programme. Price also shows that anthropologists in foreign fields were often arrested on suspicion of spying, even when they were not. Even without CIA funding, Price argues, the ethnographic research produced by anthropologists in the field provided the cultural knowledge the agency needed to support its counterinsurgency programmes.

As with all intelligence-based research, conclusions can be made only from the information declassified and released to the scholar. Despite Price's impressive achievement in gaining so much information through the Freedom of Information Act, some conclusions are made on only partial evidence. In his defence, Price acknowledges this. When summarizing the chapter on MK Ultra, for example, Price recognizes that the destruction of documentation and the classified character of secret agencies limit some of the conclusions that he can make on the subject. In spite of such restrictions, Price has amassed a considerable weight of supportive evidence for the assumptions that he does make.

There are some conclusions that Price comes to that would not surprise researchers who focus on the development of the Sunbelt in the Cold War US South. The growth of federal funding for research and development in the electronics, aeronautics and space industries was driven by the United States' battle against communism, and has been well documented before. The resultant rise in university education in the Cold War was required to provide a more skilled workforce to populate the growing industries, and anthropology departments benefited too. The GI Bill tuition, a major factor in the growth of post-war university education, also impacted on an increasing scale of anthropological research and was 'nurtured by the dual use dynamics of Cold War research needs' (p. 27). Anthropologists needed funding for research trips, travel and training and the federal government was willing to give it. In return, US departments received cutting-edge research on the peoples that it was encountering in its global diplomatic efforts. Nonetheless, despite this slight lack of originality in his findings, what these conclusions do is highlight the multidisciplinary nature of Price's work and its importance to a number of fields of research. Anthropologists, intelligence scholars and researchers of US foreign policy would all benefit from reading it.

Price's intention was to create a trilogy that illustrated how anthropologists had started as willing supporters of military and intelligence activities during the Second World War, and became opponents of the same policies during the Cold War. He does so with great success. It is a convincing and thoughtful history that would allow modern-day anthropologists to gauge how their discipline developed during the latter part of the twentieth century. The volume on FBI surveillance would, for any scholar of the bureau or McCarthyism, work well alongside more 
traditional scholarly approaches, such as that of Athan Theoharris. This final part of the trilogy would complement perfectly Loch K. Johnson's or Rhodri JeffreysJones's extensive work on the CIA. It is an authoritative interdisciplinary work that fills an important gap in the scholarship of the Cold War. 